Article

\title{
Burnout Investigation of Small Diameter Tubes Immersed in Nanofluids ${ }^{\dagger}$
}

\author{
Janusz T. Cieśliński ${ }^{1, *(D)}$ and Katarzyna Ronewicz ${ }^{2}$
}

1 Faculty of Mechanical Engineering and Ship Technology, Institute of Energy, Gdansk University of Technology, Narutowicza 11/12, 80233 Gdańsk, Poland

2 AIC S.A., Rdestowa 41, 81577 Gdynia, Poland; krygier.kasia@gmail.com

* Correspondence: jcieslin@pg.edu.pl

+ This paper is an extended version of our paper published in 2014 Eurotherm Seminar 101 Transport Phenomena in Multiphase Systems, Cracow, Poland, 30 June-3 July 2014.

check for

updates

Citation: Cieśliński, J.T.; Ronewicz, K Burnout Investigation of Small

Diameter Tubes Immersed in

Nanofluids. Energies 2021, 14, 3888.

https://doi.org/10.3390/en14133888

Academic Editor: Yulong Ding

Received: 31 May 2021

Accepted: 21 June 2021

Published: 28 June 2021

Publisher's Note: MDPI stays neutral with regard to jurisdictional claims in published maps and institutional affiliations.

Copyright: (C) 2021 by the authors. Licensee MDPI, Basel, Switzerland. This article is an open access article distributed under the terms and conditions of the Creative Commons Attribution (CC BY) license (https:/ / creativecommons.org/licenses/by/ $4.0 /)$.

\begin{abstract}
This paper deals with research into pool boiling critical heat flux $(\mathrm{CHF})$ of water- $\mathrm{Al}_{2} \mathrm{O}_{3}$ water- $\mathrm{TiO}_{2}$ and water-Cu nanofluids on horizontal stainless steel tubes. The experiments were conducted under atmospheric pressure. Nanoparticles were tested at concentrations of $0.001 \%, 0.01 \%$, $0.1 \%$ and $1 \%$ by weight. Ultrasonic vibration was used in order to stabilize the dispersion of the nanoparticles. Although dispersants were not used to stabilize the suspension, the solutions tested showed satisfactory stability. Experimental measurements were performed with stainless steel tubes of three outside diameters: 1.6, 3 and $5 \mathrm{~mm}$. Enhancement of CHF was observed to be independent of the concentration and material of the nanoparticles and tube diameter, with simultaneous heat transfer degradation. Built up during the boiling process, nanolayers improve substantially the heating surface wettability. A correlation is suggested for the CHF prediction during pool boiling of nanofluids.
\end{abstract}

Keywords: pool boiling; nanofluid; burnout; horizontal tubes; contact angle; correlation equation

\section{Introduction}

Critical heat flux (CHF) creates a limit for reactors operated with constant heat flux, e.g., chemical or nuclear reactors-hence the ceaseless work being carried out in order to improve CHF. Recently, Xie et al. [1] presented a comprehensive study on CHF enhancement techniques. Four approaches to enhancing $\mathrm{CHF}$ were distinguished. The first approach relies on improving fluid properties using different additives such as surfactant and polymer additives, and nanofluids. Liang and Mudawar [2] reviewed the literature published on the subject of the influence of additives on CHF amelioration. They stressed the combined effect of surfactants and nanofluids on CHF behavior, because surfactants are sometimes used as stabilizers for nanofluids. Key factors influencing the CHF by use of nanofluids are discussed in [3-7]. The second group of CHF enhancement techniques distinguished in [1] is concerned with surface modifications. Recently, Liang and Mudawar [8] exhaustively presented developed modification techniques involving surfaces from macro- to nanoscale. In [9-13], the role of nanocoatings created during the boiling process of nanofluids on heating surfaces on $\mathrm{CHF}$ is stressed. The third group of $\mathrm{CHF}$ enhancement techniques proposed in [1] concerns modifications of liquid-steam channels. Further details regarding this subject can be found in [14]. The last group of CHF enhancement techniques specified in [1] discusses hybrid approaches, for instance, biphilic or biconductive surfaces.

Nanofluids, as a new category of fluids, may revolutionize heat transfer technology. A nanofluid is a mixture/suspension of the base liquid and nanoparticles sized below $100 \mathrm{~nm}$ [15]. Conflicting results for the effect of nanoparticles on pool boiling heat transfer performance have been reported $[4,16,17]$. However, data published in the open literature show that application of nanofluids results in a distinct increase in $\mathrm{CHF}$-by as much as 
almost three times compared to the boiling of a pure base liquid. It seems that You et al. [18] were the first to study CHF phenomenon with nanofluids. They demonstrated that the $\mathrm{CHF}$ of water $-\mathrm{Al}_{2} \mathrm{O}_{3}$ water nanofluids, while boiling on a flat plate, was about $200 \%$ higher than that for pure water when the particle volume fraction exceeded $0.005 \mathrm{~g} / \mathrm{L}$. Furthermore, they concluded that the unusual CHF enhancement with nanofluids could not be explained by any existing model of CHF. Vassallo et al. [19] conducted experiments on NiCr wire that confirms the increasing $\mathrm{CHF}$ of nanofluids. They examined the boiling characteristics of silica-water nanofluids with $0.5 \%$ volume concentration and observed a thick $\mathrm{SiO}_{2}$ coating $(0.15-0.2 \mathrm{~mm})$ on the wire, suggesting that there was a surface interaction between the nanoparticles and the wire. Dinh et al. [20] observed an increase in CHF during the process of boiling water $-\mathrm{Al}_{2} \mathrm{O}_{3}$ nanofluid on horizontal plates covered with titanium film $(460 \mathrm{~nm})$. They postulated that the increase in CHF resulted from two premises: the formation of nanocoating and the extraordinary ability of nanofluids to wet the heater, which is called superspreading. Moreno et al. [21] established that at saturation temperature $\left(\mathrm{t}_{\text {sat }}=60{ }^{\circ} \mathrm{C}\right)$, the maximum CHF enhancement, compared to the CHF previously predicted by Zuber, evaluated at an equivalent saturation temperature, is about $180 \%$ for water- $\mathrm{Al}_{2} \mathrm{O}_{3}$ nanofluids and about $240 \%$ for water $-\mathrm{ZnO}$ nanofluids. The dispersion of $\mathrm{Al}_{2} \mathrm{O}_{3}$ nanoparticles in various ethylene glycol solutions is also found to enhance CHF by as much as $130 \%$. Bang and Chang [22] studied the pool boiling heat transfer of water$\mathrm{Al}_{2} \mathrm{O}_{3}$ nanofluids on a flat plate heater, and measured the surface roughness of the heater before and after the pool boiling experiment. They reported that the CHF was enhanced in both horizontal and vertical pool boiling. In addition, using surface roughness data, they hypothesized that the change in CHF performance was related to the change in the surface characteristics with the deposition of nanoparticles. However, these studies could not precisely determine the reason for the outstanding enhancement of the CHF when using nanofluids, and simply conjectured that the effect was related to the surface coating of nanoparticles. Milanova and Kumar [23] reported that nanosilica suspension increased CHF three times compared to water while boiling on wire. Jackson et al. [24] studied boiling of water-Au nanofluid on circular plate. They established that CHF was 1.5 times higher than for pure water. Kim et al. $[25,26]$ investigated boiling of water-based nanofluids with titania and alumina nanoparticles on $\mathrm{NiCr}$ and $\mathrm{Ti}$ wires. The results showed that the nanofluids significantly enhanced CHF compared to that of pure water (up to 170\%). Kim et al. [27,28] observed CHF enhancement during water- $\mathrm{Al}_{2} \mathrm{O}_{3}$, water $-\mathrm{ZrO}_{2}$ and water$\mathrm{SiO}_{2}$ nanofluids on wires and a flat horizontal plate. They attributed CHF enhancement to contact angle reduction. Kashinath [29] conducted experiments in order to check the effect of heater size, pressure, heater orientation and effect of antifreeze addition on CHF of water- and glycol-based nanofluids using $\mathrm{Al}_{2} \mathrm{O}_{3}$ nanoparticles. Nanofluids were shown to have about 180-200\% enhancement in CHF values. The effect of the heater was examined by using three different sized heaters. Maximum enhancement of about $190 \%$ was achieved for a $1 \times 1 \mathrm{~cm}$ heater. The effect of pressure on $\mathrm{CHF}$ was investigated by testing nanofluids at three pressures. Maximum enhancement of $\sim 240 \%$ increase in CHF was observed at the lowest pressure tested. Surface orientation effect on CHF tested for a $2 \times 2 \mathrm{~cm}$ heater at five orientations revealed about $120 \%$ enhancement over the CHF obtained using Zuber's correlation at an orientation of $150^{\circ}$. Two commercially used antifreezes, EG and PG, were used to study the effect of antifreeze in addition to nanofluids. Alumina-water nanofluid of $0.025 \mathrm{~g} / \mathrm{L}$ concentration mixed with the antifreezes at five compositions (by volume) showed a maximum enhancement of about $120 \%$ for EG and about $70 \%$ for PG. Milanova et al. [30] used water-based nanofluids with $\mathrm{SiO}_{2}, \mathrm{CeO}_{2}$ and $\mathrm{Al}_{2} \mathrm{O}_{3}$ nanoparticles. They postulated that amorphous oxides $\left(\mathrm{SiO}_{2}\right)$ were generally less orderly and less closely packed compared to the crystalline oxides such as $\mathrm{CeO}_{2}$ and $\mathrm{Al}_{2} \mathrm{O}_{3}$. The arrangement of the atoms within the unit cell and the layer of water molecules at the surface may possibly influence CHF. The boiling regime was further extended to higher heat flux when there was agglomeration on the wire. These agglomerations allowed for high heat transfer through interagglomerate pores, resulting in an almost tripled CHF. This deposition occurred for 
the charged $10 \mathrm{~nm}$ silica particle but was not seen for other oxide particles. Kim et al. [31] determined that the addition of $\mathrm{TiO}_{2}$ resulted in $200 \%$ of $\mathrm{CHF}$ during boiling on a $\mathrm{NiCr}$ wire compared to that of pure water by increasing nanoparticle concentration. $\mathrm{Kim} \mathrm{H}$. and Kim D. [32] noticed CHF enhancement during boiling of water- $\mathrm{TiO}_{2}$, water- $\mathrm{Al}_{2} \mathrm{O}_{3}$, water$\mathrm{SiO}_{2}$ nanofluids, while no augmentation of $\mathrm{CHF}$ was observed for water-Ag nanofluid. They concluded that the significant CHF enhancement was not only a consequence of increased surface wettability but also improved capillarity due to the surface deposition of nanoparticles. Kim et al. [33] established that CHF was degraded while boiling nanofluids on a nanoparticle-coated heating surface because nanoparticles may clog micropasses supplying the bulk liquid to the heating surface by capillary wicking. Liu et al. [34] studied pool boiling of water-CuO nanofluid on a horizontal copper plate with microgrooves. The grooves were $0.5 \mathrm{~mm}$ wide and $0.8 \mathrm{~mm}$ deep. The gap between the two grooves was $0.5 \mathrm{~mm}$. The experiments were conducted under four different operating pressures: 7.4, 20, 31.2 and $100 \mathrm{kPa}$, as CHF enhancement strongly depends on operating pressure. CHF for optimum nanoparticle concentration of $1 \%$ and operating pressure of $7.4 \mathrm{kPa}$ was about twice as high as that for pure water. Coursey and Kim [35] researched the effects of boiling water $-\mathrm{Al}_{2} \mathrm{O}_{3}$ and ethanol- $\mathrm{Al}_{2} \mathrm{O}_{3}$ nanofluids on circular plates made of glass, $\mathrm{Au}$ and $\mathrm{Cu}$. They noticed that the greater concentrations led to a modest increase in CHF (up to 37\%). Liu and Liao [36] postulated that the very thin nanoparticle sorption layer caused a decrease in solid-liquid contact angle on the heating surface, which led to an increase in CHF. Milanova and Kumar [37] determined that when there was no nanoparticle deposition on the wire, the nanofluid water- $\mathrm{SiO}_{2}$ increased $\mathrm{CHF}$ by about $50 \%$ regardless of the $\mathrm{pH}$ of the base liquid $(3,4,7,10)$ or particle size $(10-20 \mathrm{~nm})$. Golubovic et al. [38] revealed that the increase in nanoparticle concentration in the nanofluid increased CHF up to a certain point, after which further increase did not affect CHF. In other words, they believe in the hydrodynamic nature of CHF. Jo et al. [39] established that CHF was significantly enhanced for different nanoparticle sizes and concentrations. The CHF of nanofluids was increased as the size of the nanoparticles decreased. On the other hand, data for nanoparticle concentration showed that the maximum CHF had a critical value. Kumar and Milanova [40] demonstrated that $\mathrm{CHF}$ was the powerful effect of the relaxation of surface tension in the nanofluid, i.e., the difference in surface tension between a nanofluid and surfactant solution. The maximum enhancement in CHF is nearly four times more than that of a surfactant to $\mathrm{CNT}$ concentration ratio of 1:5. Kim H. and Kim M. [41] reported outstanding $\mathrm{CHF}$ improvement during the process of boiling water- $\mathrm{TiO}_{2}$, water- $\mathrm{Al}_{2} \mathrm{O}_{3}$ and water $-\mathrm{SiO}_{2}$ nanofluids on horizontal wire. The final effect depends strongly on the kind of nanoparticles, and its concentration $\left(10^{-5}-10^{-1}\right.$ vol.\%). Park et al. [42] stressed that an improvement in CHF resulted from CNT deposition and formation of a thin film on the surface. Because of this deposition, the probability of forming a large vapor blanket with bubbles at high heat flux decreased and, consequently, CHF increased. Kim et al. [43] established that the quenching behavior of nanofluids was nearly identical to that of pure water. However, it was found that some nanoparticles accumulated on the sphere surface, which resulted in the destabilization of the vapor film in subsequent tests with the same sphere, thus greatly accelerating the quenching process. Kathiravan et al. [44] found that CHF increased in line with nanoparticle concentration during the process of boiling water-Cu nanofluid on a $30 \mathrm{~mm}$-square flat plate. However, the addition of surfactant (SDS) to nanofluid resulted in dramatic $\mathrm{CHF}$ degradation. Kwark et al. [45] carried out experiments involving boiling water- $\mathrm{Al}_{2} \mathrm{O}_{3}$, water- $\mathrm{CuO}$ and water-diamond nanofluids. They postulated that there was an optimal nanocoating thickness/structure that could produce the maximum CHF enhancement. Furthermore, it seems that boiling itself appears to be the mechanism responsible for the formation of nanoparticle coating as the vapor bubble microlayer evaporates. Kwark et al. [46,47] conducted experiments involving boiling pure water on a plate covered with nanocoating created during ethanol- $\mathrm{Al}_{2} \mathrm{O}_{3}$ nanofluid. When tested in water, these nanocoatings had the ability to enhance CHF. Kwark et al. showed that pool boiling performance of pure water on $\mathrm{Al}_{2} \mathrm{O}_{3}$ nanoparticle coated flat heaters depended on 
such parameters as operating pressure, heater size and heater orientation. They postulated that the better wettability in the nanocoating, especially its ability to continuously rewet the base of the growing bubbles, was the main cause of CHF enhancement. Liu et al. [48] experimentally demonstrated that pressure significantly influences $\mathrm{CHF}$ of CNT nanofluids. They postulated that CHF depends on the thickness and the wettability area of the thin liquid microlayer underneath vapor bubble. If the CNT nanoparticles accumulated in the liquid microlayer during the boiling process, the CHF can be increased in line with both the effective thermal conductivity and the wettability area of the thin liquid microlayer. Under atmospheric pressure, the effects of the accumulation of CNTs in the thin liquid microlayer may be weak since it is difficult for nanoparticles to enter into the liquid microlayer. However, under subatmospheric pressure, the effects of accumulation may be stronger than for atmospheric pressure, so heat transfer enhancement would increase as pressure decreased. Kim et al. [49] recorded significant CHF enhancement during the process of boiling alumina $\left(\mathrm{Al}_{2} \mathrm{O}_{3}\right)$ and titania $\left(\mathrm{TiO}_{2}\right)$ nanofluids on a heated disk. It is supposed that the nanoparticle layer increases the stability of the evaporating microlayer underneath a bubble growing on a heated surface, and thus the irreversible growth of a hot/dry spot is inhibited even at high wall superheat, resulting in the CHF enhancement observed when boiling nanofluids. Park et al. [50] used graphene and graphene oxide nanosheets (GON) as additives in nanofluids, and they recorded an outstanding CHF improvement, especially for the water-GON nanofluid (179\%). As a potential explanation, Park et al. suggest that applying GON results in building a characteristically ordered porous surface structure due to its own self-assembly characteristics, resulting in a geometrically changed critical Rayleigh-Taylor instability wavelength. Truong et al. [51] determined that nanofluids could further increase pool boiling CHF by forming a porous deposition on the heated surface. They tested three water-based nanofluids (diamond, zinc oxide and alumina) to modify sandblasted stainless steel 316 plate heaters by boiling-induced deposition. The pool boiling CHF of these precoated heaters increased by up to $35 \%$ with respect to that of the bare sandblasted heaters. The enhancements are at their highest for alumina and zinc oxide nanofluids. Kathiravan et al. [52] observed a CHF increase with concentration of silver nanoparticles suspended in water and in water-surfactant base liquid. Park et al. [53] used $x G n P s$ and $x G n P s$ oxide to prepare experimental nanofluids. The CHF of nanofluids when boiled over a $\mathrm{NiCr}$ wire increased with increasing concentrations of $x \mathrm{GnP}$ and $\mathrm{xGnP}$ oxide particles in the base fluid. They noticed the xGnP oxide nanofluids with 0.005 vol. $\%$ dispersed particle concentration had the most enhanced CHF. Although the largest CHF enhancement was observed for the nanofluid with 0.005 vol.\% xGnP oxide, no reduction was observed in the contact angle. Lee et al. [54] described the effect of high pressure on CHF enhancement using water-based nanofluids. They found that the CHF was generally increased by increasing system pressure. Hiswankar and Kshirsagar [55] studied pool boiling with water-based nanofluid and $\mathrm{ZnO}$ nanoparticles. The results showed that water-based nanofluids significantly enhanced CHF compared to that of pure water. The $\mathrm{CHF}$ values of the $\mathrm{ZnO}$ nanofluids were enhanced from approximately $70 \%$ to $80 \%$ of pure water. It was found that a sizeable layer of nanoparticle deposits were formed on the heater surface. Park et al. [56] studied the $\mathrm{Ag}, \mathrm{Cu}$ and $\mathrm{Al}_{2} \mathrm{O}_{3}$ nanofluids produced by the electrical explosion of wire in liquids (EEWL). The EEWL as physical method has many advantages, such as high-purity nanofluid production without surfactants (nontoxic, in contrast to the chemical method), control of nanoparticle surface oxidation and spherical nanoparticle production. They performed pool boiling experiments to characterize the $\mathrm{CHF}$ enhancement using $\mathrm{Ag}, \mathrm{Cu}$ and $\mathrm{Al}_{2} \mathrm{O}_{3}$ nanofluids. The heater surface contained deposited nanoparticles that formed nano/microstructures. Build-up of the nanoparticles on the heater surface occurred during nucleate boiling, which decreased the contact angle of heater surface. The improvement in surface wettability contributed to the CHF enhancement. Kole et al. [57] studied the pool boiling characteristics of copper-distilled water nanofluids that were determined by use of cylindrical heater surfaces of three different materials, such as copper, brass and aluminum. They showed that the heat transfer 
coefficient during boiling was enhanced for all three heating surfaces with increasing concentration of copper nanoparticles in the prepared nanofluids and roughness of surfaces. Moreover, it depended on the material of surface. They observed that CHF increased with increasing $\mathrm{Cu}$ nanoparticle concentration and displayed a maximum enhancement of about $60 \%$ for nanofluid containing $0.5 \mathrm{wt} . \%$ of copper. The CHF enhancement was attributed to the increased surface roughness of the heating wire due to the formation of peaks and valleys on the wire surface. Song et al. [58] studied CHF enhancement in water and $\mathrm{SiC}$ nanofluid during pool boiling. The volume concentrations of $\mathrm{SiC}$ nanofluid were $0.0001 \%, 0.001 \%, 0.01 \%$. The experiments were conducted under atmospheric pressure. The CHF was enhanced up to $105 \%$ for a volume concentration of $0.01 \%$ and did not depend linearly on nanoparticle concentration. The change in the wettability of the SiC nanoparticle deposited surface was cited as the main reason of CHF enhancement variation. Sarafraz et al. [59] studied HTC during boiling and CHF of functionalized carbon nanotubes (FCNT), and nonfunctionalized carbon nanotubes (CNT) with nanoparticle concentration of 0.1 to $0.3 \mathrm{wt} . \%$. They found that CHF generally increased in line with the concentration of nanofluid. However, the greatest CHF enhancement was observed for the FCNT nanofluid with $0.3 \mathrm{wt} . \%$, which was $31.1 \%$ higher than the figure obtained for pure deionized water. He et al. [60] studied heat transfer characteristics during pool boiling, including HTC and CHF of ethylene glycol (EG) and $\mathrm{ZnO}$ nanofluids based on deionized water. The experiments were conducted in a cylindrical vessel under atmospheric pressure. They noticed a significant enhancement of CHF between nanofluids and their respective base fluids. The CHF was enhanced due to the reduction of surface wettability and nanoparticle coating on the heating surface. The largest CHF enhancement was observed for the nanofluid of 0.75 vol. $\%$, which was $77.4 \%$ higher than the figure obtained for base fluids. Sulaiman et al. [61] tested the heat transfer characteristics and CHF in saturated pool boiling of water-based nanofluids. An upward-facing copper surface of $20 \mathrm{~mm}$ in diameter was used as the heating surface. The nanoparticles used as part of the research were $\mathrm{TiO}_{2}, \mathrm{Al}_{2} \mathrm{O}_{3}$ and $\mathrm{SiO}_{2}$ with mass concentrations of $0.04,0.4$ and $1 \mathrm{~kg} / \mathrm{m}^{3}$. Under all the experimental conditions, the CHF in nanofluids was 2.5-3 times higher than the respective figure for pure water. Ham et al. [62] researched the influence of surface roughness on the boiling characteristics of nanofluids during a pool boiling experiment with different concentrations of $\mathrm{Al}_{2} \mathrm{O}_{3}$ nanofluid. They used surfaces with $\mathrm{R}_{\mathrm{a}}=177.5 \mathrm{~nm}$ and $\mathrm{R}_{\mathrm{a}}=292.8 \mathrm{~nm}$. The CHF of $\mathrm{Al}_{2} \mathrm{O}_{3}$ nanofluid was higher than that of the base fluid, but the improvement in the CHF was affected by the surface roughness. They observed that CHF increased in line with nanoparticle concentration. As the concentration of nanofluid increased from 0 to $0.05 \mathrm{vol} . \%$, it was found that the CHF on the surfaces with $R_{a}=177.5 \mathrm{~nm}$ and $\mathrm{R}_{\mathrm{a}}=292.8 \mathrm{~nm}$ improved by $224.8 \%$ and $138.5 \%$, respectively. However, when the concentration was over 0.05 vol. \%, the improvement of the CHF decreased for both surfaces-the improvement in the CHF decreased from $225.1 \%$ to $124.8 \%$. Kim et al. [63] studied CHF in water-based nanofluids using alumina and reduced graphene oxide (RGO) nanoparticles. A substantial CHF augmentation of $473 \%$ was noticed for the nanofluid with $\mathrm{Al}_{2} \mathrm{O}_{3}$ and RGO nanoparticles mixed at 0.0005 vol.\% of each. Recently, Hwang et al. [64] researched $\mathrm{CHF}$ in water-cellulose nanofluids. As the concentration of cellulose nanofibers increased from $0.01 \mathrm{wt} . \%$ to $0.1 \mathrm{wt} . \%$, it was found that CHF increased from $40.7 \%$ to $69.4 \%$ compared to pure water.

Tables 1 and 2 provide summaries of experimental studies dealing with CHF of nanofluids on thin wires and plates, respectively. Table 3 shows experimental studies regarding $\mathrm{CHF}$ in nanofluids on other geometries. 
Table 1. Review of experimental studies on CHF of nanofluids in pool boiling on wires.

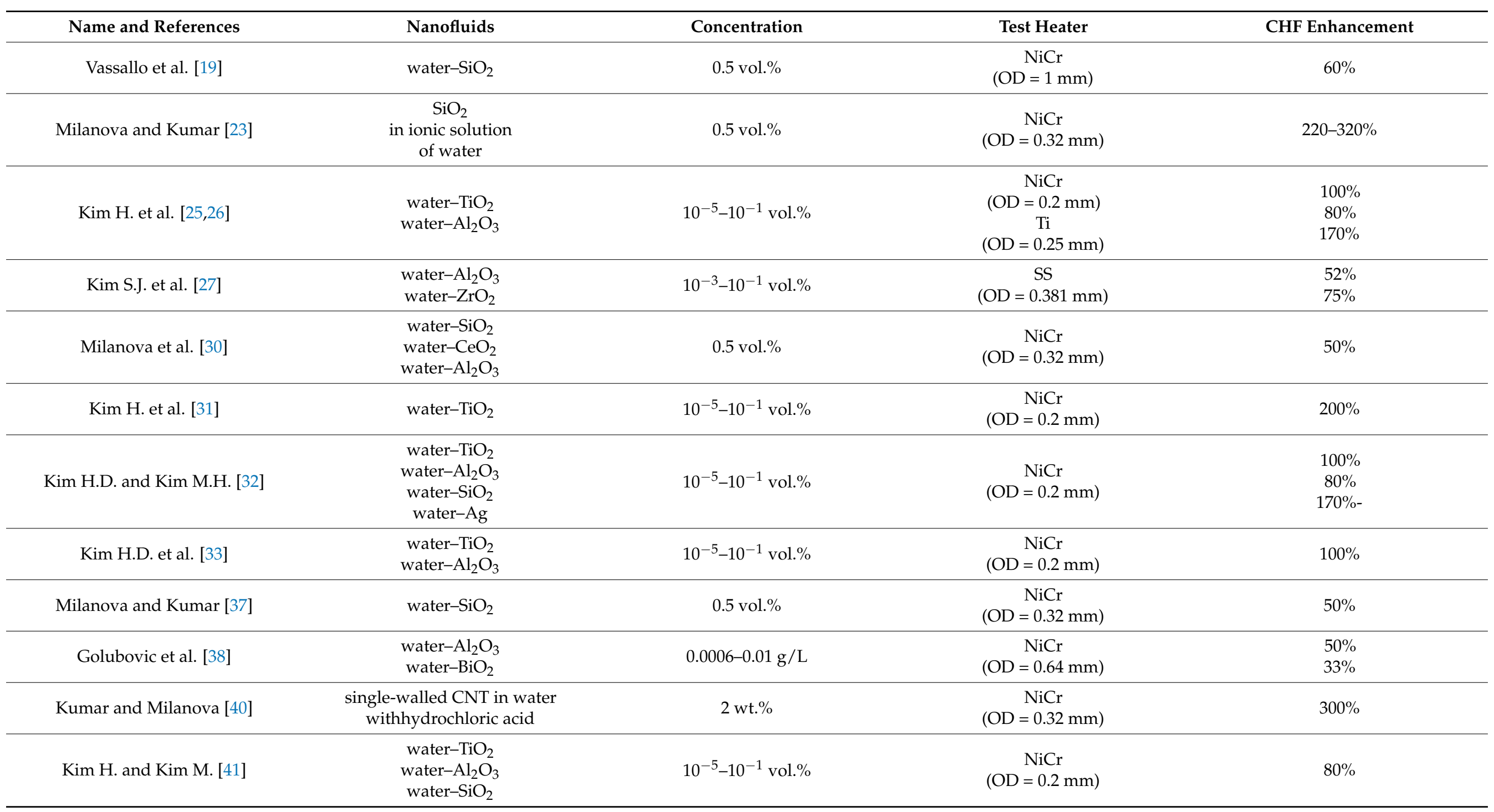


Table 1. Cont.

\begin{tabular}{|c|c|c|c|c|}
\hline Name and References & Nanofluids & Concentration & Test Heater & CHF Enhancement \\
\hline Park S.D. et al. [50] & $\begin{array}{c}\text { water-graphene } \\
\text { water-GON } \\
\text { water- } \mathrm{Al}_{2} \mathrm{O}_{3}\end{array}$ & 0.001 vol. $\%$ & $\mathrm{NiCr}$ & $\begin{array}{l}84 \% \\
179 \% \\
152 \% \\
\end{array}$ \\
\hline Park E.J. et al. [53] & $\begin{array}{l}x G n P s \text { oxide } \\
x G n P s \text { oxide }\end{array}$ & 0.005 vol. $\%$ & $\mathrm{NiCr}$ & enhanced CHF \\
\hline Lee T. et al. [54] & water-magnetite & $1 \mathrm{ppm}$ & $\begin{array}{c}\mathrm{Ni}-\mathrm{Cr} \\
\mathrm{OD}=0.4 \mathrm{~mm}\end{array}$ & $140 \%$ to $170 \%$ \\
\hline Park E. et al. [56] & $\begin{array}{c}\text { water- } \mathrm{Ag} \\
\text { water- } \mathrm{CuO} \\
\text { water } \mathrm{Al}_{2} \mathrm{O}_{3}\end{array}$ & 0.001 vol. $\%$ & $\mathrm{Ni}-\mathrm{Cr}$ & $\begin{array}{r}58 \% \\
99 \% \\
108 \% \\
\end{array}$ \\
\hline Kole and Dey [57] & water-Cu & 0.5 wt. $\%$ & $\begin{array}{l}\text { Constantan } \\
\mathrm{OD}=70 \mu \mathrm{m}\end{array}$ & $\sim 60 \%$ \\
\hline He et al. [60] & ZnO-EG-DW (EG-water) & $\begin{array}{l}5.25 \text { wt. } \% \\
7.25 \text { wt. } \% \\
8.25 \text { wt. } \%\end{array}$ & $\begin{array}{c}\mathrm{Ni}-\mathrm{Cr} \\
(0.5 \mathrm{~mm} \times 5 \mathrm{~cm})\end{array}$ & $\begin{array}{l}156.7 \% \\
161.2 \% \\
177.4 \%\end{array}$ \\
\hline Kim J.H. et al. [63] & $\begin{array}{c}\text { water- } \mathrm{Al}_{2} \mathrm{O}_{3} \\
\text { water-RGO } \\
\text { water- } \mathrm{Al}_{2} \mathrm{O}_{3} / \mathrm{RGO}\end{array}$ & $\begin{array}{c}(0.0001-0.01 \text { vol. } \%) \\
(0.00005-0.005 \text { vol. } \%) \\
0.0005 \text { vol. } \% \mathrm{Al}_{2} \mathrm{O}_{3} \text { and } \mathrm{RGO}\end{array}$ & $\begin{array}{c}\mathrm{Ni}-\mathrm{Cr} \\
(0.2 \times 85) \mathrm{mm}\end{array}$ & $\begin{array}{l}54 \% \\
37 \% \\
473 \%\end{array}$ \\
\hline Hwang et al. [64] & water-cellulose & $0.01-0.1$ wt. $\%$ & $\begin{array}{c}\mathrm{Ni}-\mathrm{Cr} \\
(0.1 \times 150) \mathrm{mm}\end{array}$ & \\
\hline
\end{tabular}


Table 2. Review of experimental studies on CHF of nanofluids in pool boiling on plates.

\begin{tabular}{|c|c|c|c|c|}
\hline Name and References & Nanofluids & Concentration & Test Heater & CHF Enhancement \\
\hline You et al. [18] & water- $\mathrm{Al}_{2} \mathrm{O}_{3}$ & $0.001-0.025 \mathrm{~g} / \mathrm{L}$ & Cu plate $(10 \times 10 \mathrm{~mm})$ & $200 \%,(19.9 \mathrm{kPa})$ \\
\hline Dinh et al. [20] & water $-\mathrm{Al}_{2} \mathrm{O}_{3}$ & 37 ppm solution & $\begin{array}{c}\text { Ti plate } \\
(26.5 \times 40 \mathrm{~mm})\end{array}$ & - \\
\hline Moreno et al. [21] & $\begin{array}{c}\text { water- } \mathrm{Al}_{2} \mathrm{O}_{3} \\
\text { water- } \mathrm{ZnO} \\
\mathrm{EG}-\mathrm{Al}_{2} \mathrm{O}_{3}\end{array}$ & $0.001-1 \mathrm{~g} / \mathrm{L}$ & $\begin{array}{c}\text { Cu plate } \\
10 \times 10 \mathrm{~mm}\end{array}$ & $\begin{array}{l}180 \% \\
240 \% \\
130 \%\end{array}$ \\
\hline Bang and Chang [22] & water- $-\mathrm{Al}_{2} \mathrm{O}_{3}$ & $0.5-4$ vol. $\%$ & plate & $\begin{array}{c}220 \% \text {-horizontal } \\
160 \% \text {-vertical }\end{array}$ \\
\hline Jackson J. et al. [24] & water-Au & $3 \cdot 10^{-4}$ vol. $\%$ & $\begin{array}{l}\text { Circular plate } \\
(11.2 \mathrm{~mm})\end{array}$ & $250 \%$ \\
\hline Kim S.J. et al. [28] & water- $\mathrm{SiO}_{2}$ & $10^{-3}-10^{-1}$ vol. $\%$ & $\begin{array}{l}\text { SS flat plate } \\
(5 \times 45 \mathrm{~mm})\end{array}$ & $80 \%$ \\
\hline Kashinath [29] & $\mathrm{Al}_{2} \mathrm{O}_{3}$ in $\mathrm{EG}$ and $\mathrm{PG}$ in water & $0.025 \mathrm{~g} / \mathrm{L}$ & $\begin{array}{c}\text { Cu plate } \\
(10 \times 10 \mathrm{~mm}) \\
(15 \times 15 \mathrm{~mm}) \\
(20 \times 20 \mathrm{~mm})\end{array}$ & $\begin{array}{c}90 \% \\
170 \% \\
70 \% \\
230 \%(7.38 \mathrm{kPa}) \\
\end{array}$ \\
\hline Liu et al. [34] & water-CuO & $0.1-2$ wt. $\%$ & $\mathrm{Cu}$ plate with microgrooves & $\begin{array}{l}50 \%(\sim 100 \mathrm{kPa}) \\
200 \%(7.4 \mathrm{kPa})\end{array}$ \\
\hline Coursey and Kim [35] & $\begin{array}{l}\text { water- }-\mathrm{Al}_{2} \mathrm{O}_{3} \\
\text { ethanol- } \mathrm{Al}_{2} \mathrm{O}_{3}\end{array}$ & $0.001-10 \mathrm{~g} / \mathrm{L}$ & Glass, $\mathrm{Au}\left(0.9 \mathrm{~cm}^{2}\right)$ and $\mathrm{Cu}\left(2 \mathrm{~cm}^{2}\right)$ & $40 \%$ \\
\hline Liu and Liao L. [36] & $\begin{array}{c}\mathrm{CuO} \\
\mathrm{SiO}_{2} \text { in } \\
\text { water and alcohol with SDBS }\end{array}$ & $0.2-2$ wt. $\%$ & $\begin{array}{c}\text { Cu disk } \\
(\mathrm{OD}=20 \mathrm{~mm})\end{array}$ & $30 \%$ \\
\hline Jo et al. [39] & $\begin{array}{c}\text { water- }-\mathrm{Al}_{2} \mathrm{O}_{3} \\
\text { water- } \mathrm{Ag}\end{array}$ & $10^{-4}-10^{-1} \mathrm{~g} / \mathrm{L}$ & $\begin{array}{c}\text { Cu disk } \\
(\mathrm{OD}=10 \text { and } \\
15 \mathrm{~mm})\end{array}$ & $70 \%$ \\
\hline Park K.J. et al. [42] & $\begin{array}{l}\text { multiwalled CNT in water with } \\
\text { PVP polymer }\end{array}$ & $\begin{array}{l}10^{-4}-10^{-2} \\
0.05 \text { vol. } \%\end{array}$ & $\begin{array}{c}\text { Cu plate } \\
(9.5 \times 9.5 \mathrm{~mm})\end{array}$ & $\begin{array}{l}200 \%(19.9 \mathrm{kPa}) \\
140 \%(19.9 \mathrm{kPa})\end{array}$ \\
\hline Kathiravan et al. [44] & $\begin{array}{c}\mathrm{Cu} \\
\text { in water } \\
\text { w/SDS surfactant } \\
\text { w/o SDS surfactant }\end{array}$ & $0.25,0.5,1.0$ wt. $\%$ & $\begin{array}{c}\text { plate } \\
(30 \times 30 \mathrm{~mm})\end{array}$ & $\begin{array}{l}50 \% \\
30 \%\end{array}$ \\
\hline
\end{tabular}


Table 2. Cont

\begin{tabular}{|c|c|c|c|c|}
\hline Name and References & Nanofluids & Concentration & Test Heater & CHF Enhancement \\
\hline Kwark et al. [45] & $\begin{array}{c}\text { water- }-\mathrm{Al}_{2} \mathrm{O}_{3} \\
\text { water-CuO } \\
\text { water-diamond }\end{array}$ & $0.001-1 \mathrm{~g} / \mathrm{L}$ & $\begin{array}{c}\text { Cu plate } \\
(10 \times 10 \mathrm{~mm})\end{array}$ & $80 \%$ \\
\hline Liu et al. [48] & CNT in water with nitric acid forpH 6.5 & $0.5-4$ wt. $\%$ & $\begin{array}{c}\text { Cu plate } \\
(40 \times 40 \mathrm{~mm})\end{array}$ & $\begin{array}{c}60 \%(100 \mathrm{kPa}) \\
140 \%(31.2 \mathrm{kPa}) \\
200 \%(7.4 \mathrm{kPa})\end{array}$ \\
\hline Kim H. et al. [49] & $\begin{array}{c}\text { water- } \mathrm{TiO}_{2} \\
\text { water- }-\mathrm{Al}_{2} \mathrm{O}_{3}\end{array}$ & 0.01 vol. $\%$ & $\begin{array}{c}\mathrm{Cu} \text { and } \mathrm{Ni} \text { discs } \\
(\mathrm{OD}=20 \mathrm{~mm})\end{array}$ & $40 \%$ \\
\hline Truong et al. [51] & $\begin{array}{l}\text { water-diamond } \\
\text { water- } \mathrm{Al}_{2} \mathrm{O}_{3} \\
\text { water- } \mathrm{ZnO}\end{array}$ & $\begin{array}{l}0.01 \text { vol. } \% \\
0.1 \text { vol. } \% \\
0.1 \text { vol. } \%\end{array}$ & Cu plate & $\begin{array}{l}11 \% \\
35 \% \\
35 \%\end{array}$ \\
\hline Kathiravan et al. [52] & $\begin{array}{c}\text { water-Cu } \\
\text { water-Cu-SDS }\end{array}$ & $0.25,0.5,0.75$ wt. $\%$ & $\begin{array}{c}\text { plate } \\
(30 \times 30 \mathrm{~mm})\end{array}$ & $\begin{array}{l}20 \% \\
40 \% \\
48 \%\end{array}$ \\
\hline Song et al. [58] & $\begin{array}{c}\text { water } \\
\text { water-SiC }\end{array}$ & $0.0001,0.001,0.01$ vol. $\%$ & $\begin{array}{c}\text { SS plate } \\
(10 \mathrm{~mm} \times 50 \mathrm{~mm} \times 0.4 \mathrm{~mm} ; \\
50 \mathrm{~mm} \times 50 \mathrm{~mm} \times 0.4 \mathrm{~mm})\end{array}$ & $105 \%$ (0.01vol. $\%)$ \\
\hline Sarafraz et al. [59] & $\begin{array}{l}\text { water-FCNT } \\
\text { water-CNT }\end{array}$ & 0.1 to 0.3 wt. $\%$ & $\begin{array}{l}\text { discoid } \mathrm{Cu} \text { heater } \\
\quad\left(0.78 \mathrm{~cm}^{2}\right)\end{array}$ & Max. $131.1 \%$ (0.3 wt. $\%)$ \\
\hline Sulaiman et al. [61] & $\begin{array}{c}\text { water- } \mathrm{TiO}_{2} \\
\text { water- } \mathrm{Al}_{2} \mathrm{O}_{3} \\
\text { water- }-\mathrm{SiO}_{2}\end{array}$ & $\begin{array}{c}0.04 \mathrm{~kg} / \mathrm{m}^{3} \\
0.4 \mathrm{~kg} / \mathrm{m}^{3} \\
1 \mathrm{~kg} / \mathrm{m}^{3}\end{array}$ & Cu block $(\mathrm{OD}=20 \mathrm{~mm})$ & 2.5-3 times higher \\
\hline Ham et al. [62] & water- $\mathrm{Al}_{2} \mathrm{O}_{3}$ & $0.001-0.1$ vol. $\%$ & Cu block $\left(\mathrm{R}_{\mathrm{a}}=177.5 \mathrm{~nm}, \mathrm{R}_{\mathrm{a}}=292.8 \mathrm{~nm}\right)$ & $\begin{array}{l}224.8 \% \\
138.5 \%\end{array}$ \\
\hline
\end{tabular}


Table 3. Review of experimental studies on CHF of nanofluids in pool boiling on other surfaces.

\begin{tabular}{ccccc}
\hline & $\mathrm{Al}_{2} \mathrm{O}_{3}$ & \multicolumn{3}{c}{ Sphere } \\
Kim H. et al. [43] & $\mathrm{SiO}_{2}$ & $0.001,0.01$, & $\mathrm{SS}(\mathrm{D}=9.5 \mathrm{~mm})$, & Quenching \\
& Diamond & 0.1 vol.\% & Zircaloy & \\
& & $(\mathrm{D}=10 \mathrm{~mm})$ & \\
\hline
\end{tabular}

All results in the published papers are connected with research on CHF in nanofluids using wires, flat plates or block plates. However, some experimental and theoretical studies show that CHF is strongly dependent on heater geometry [3,65]. Moreover, as mentioned in [66], Zuber's commonly accepted correlation for CHF prediction $[67,68]$ fails in the case of thin wires. Therefore, the main aim of this study is to recognize the phenomena of the nucleate boiling crisis of selected nanofluids during the process of boiling on horizontal tubes of various outside diameters. Of particular interest is the impact of the contact angle and tube diameter on CHF. The results shed more light on the nature of the nucleate boiling crisis and may serve as a basis for future theoretical modeling of this crisis.

\section{Experimental Apparatus and Procedure}

Figure 1 shows a schematic diagram of the experimental apparatus used. Essentially, it consisted of the test chamber, a horizontal heating tube, a condenser with cooling water circuit, a measuring system and an electric power supply system. The test chamber consisted of a cuboidal vessel made of stainless steel with inside dimensions of $150 \times 150 \times 250 \mathrm{~mm}$. The vessel was cased with an aluminum sheet and insulated with glass wool, $5 \mathrm{~cm}$ in thickness. The flow rate of cooling water through the condenser was regulated by a manual valve and measured by a flow meter. Electric power supply system consisted of two autotransformers. A Kewtech KT200 multimeter (Kewtech Corporation Ltd., Chesham, UK) was employed to measure current and voltage drop. Moreover, a safety valve and drain valve were mounted in the test vessel.

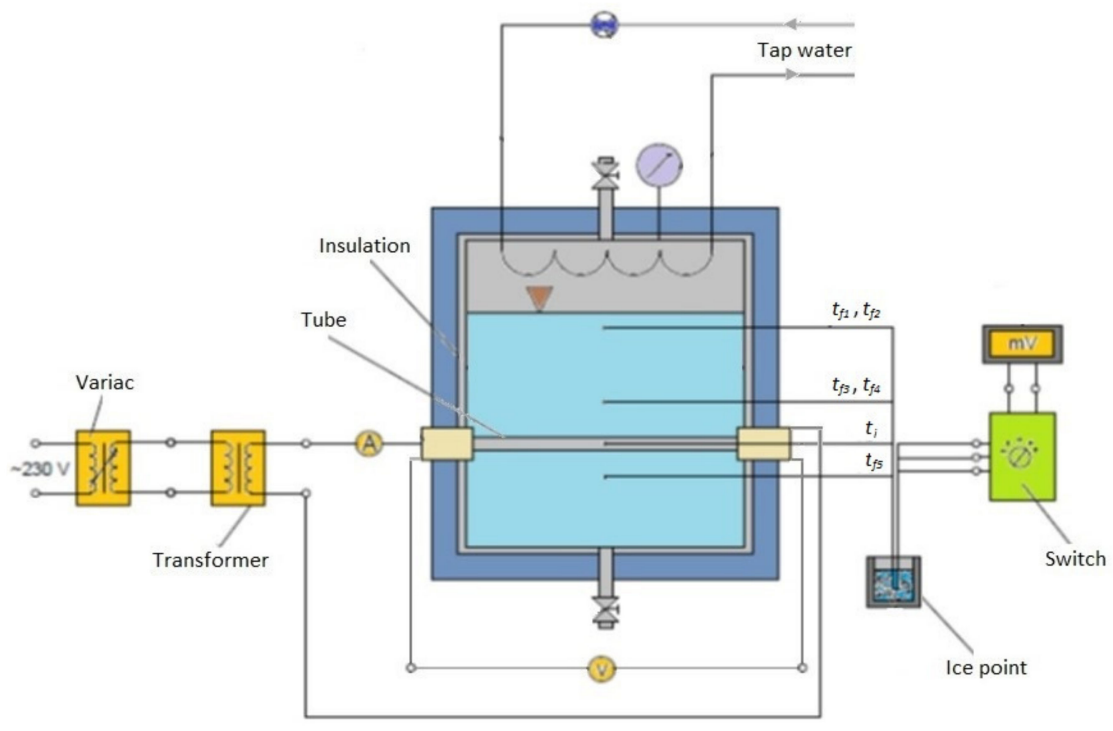

Figure 1. Scheme of the experimental rig.

Commercially available stainless steel (316L) tubes delivered by Metal-E (Mszana Dolna, Poland) with outer diameter of 1.6, 3.0 and $5.0 \mathrm{~mm}$ and inside diameter 1.1, 2.5, and 4.3 , respectively, were used to fabricate test heaters. The effective length of a heating tube was $180 \mathrm{~mm}$. The mean surface roughness was estimated to be $0.2 \mu \mathrm{m}$ and was measured by a Hommel tester T500 from Hommelwerke GmbH (VS-Schwenningen, Germany). The test specimens were heated by using the tubes themselves as resistance heaters. In order to reduce clamp resistance, both ends of the tubes were soldered to copper blocks (Figure 2). The temperature of the inside surface of the test tube was measured by a 
K-type thermocouple from Czaki Thermo-Product (Raszyn, Poland). The hot junction was placed on the center line of the tube at the midpoint of the test section. To avoid air convection currents inside the test section, both ends of the tube were closed and filled with glass wool.

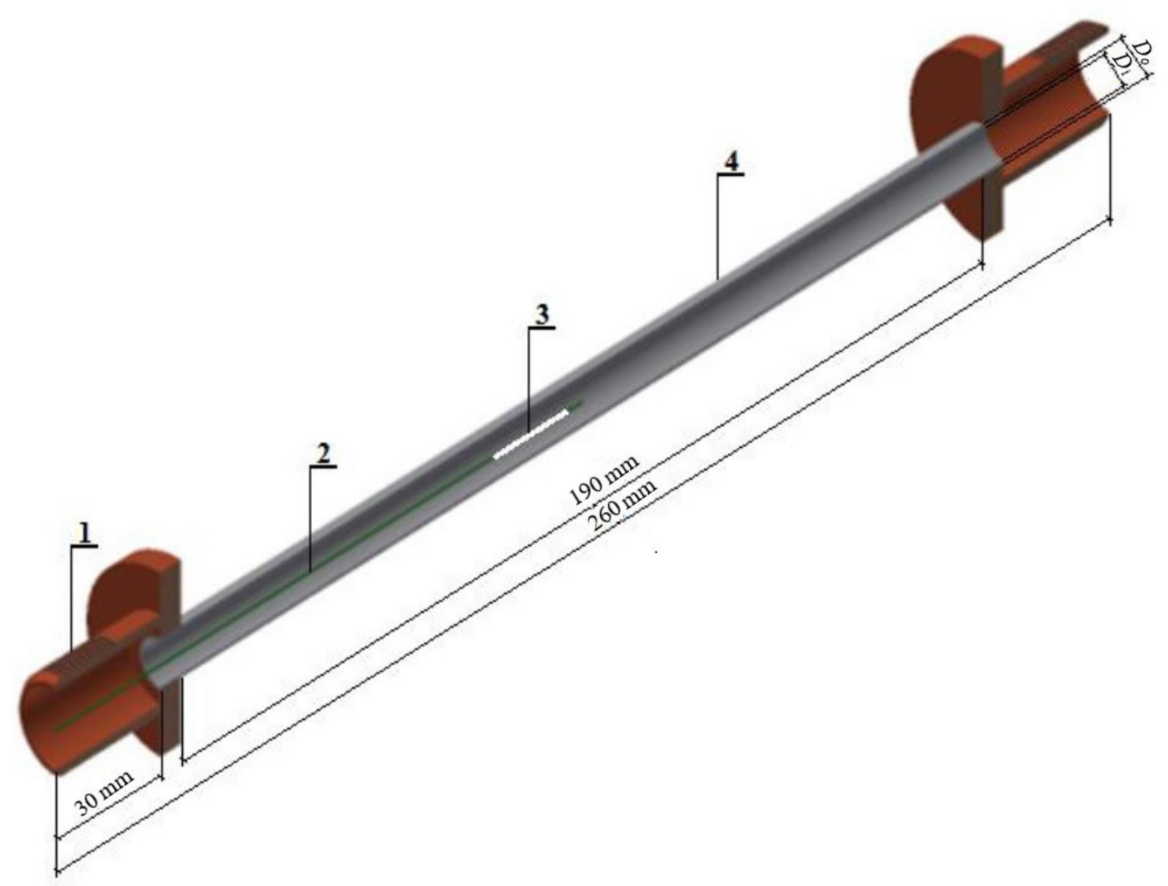

Figure 2. Details of the test section: 1-copper blocks, 2-K-type thermocouple, 3-centering ring (Teflon), 4-heating surface.

In order to ensure consistent surface state after each test, the boiling surface was prepared in the same manner: the surface of the tube was roughed, first with emery paper 180 , then 1000, and finally polished with an abrasive compound. Finally, the test tube was placed in an ultrasonic cleaner for $30 \mathrm{~min}$ and cleaned by using a distilled water jet.

Fresh nanofluid at a preset concentration was charged and then preheated to nearsaturation temperature by an auxiliary heater placed in the test vessel. Next, power was supplied to the test tube. Measurements were started at the lowest power input. Data were collected by increasing the heat flux in small increments. During each run, successive sets of the thermocouple outputs were taken and processed until the readings at each power level differed only by random amounts so that the averages were duplicated. This was perceived as an indication that the boiling process was performed at a steady rate. On average, it took approximately fifteen minutes to achieve stable conditions after the power level was changed. The power level was increased until burnout point was reached. As an example, Figure 3 displays a sequence of photographs of the burnout process during water boiling on a stainless steel tube with $D_{o}=3 \mathrm{~mm}$. 


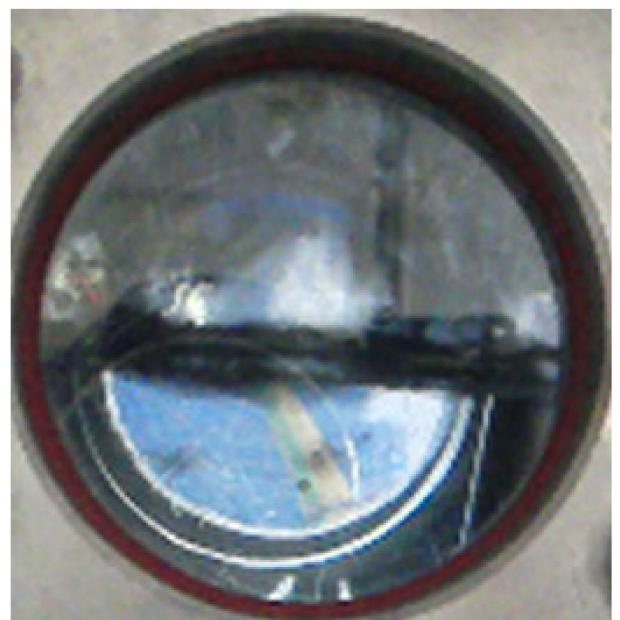

(a)

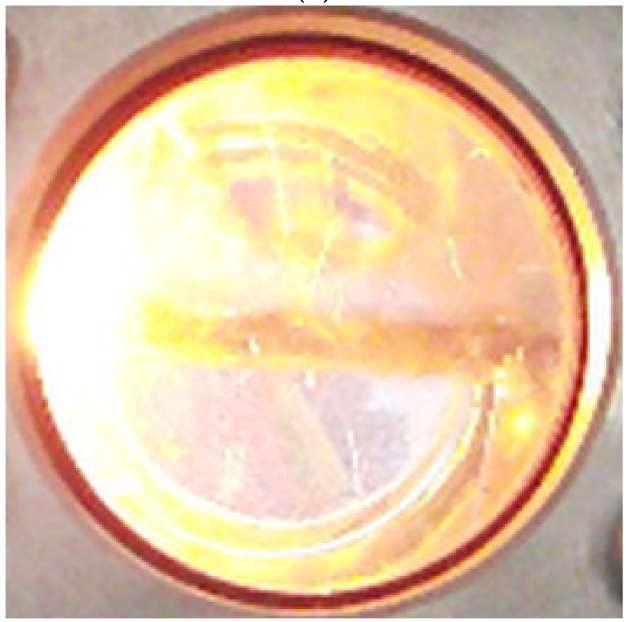

(c)

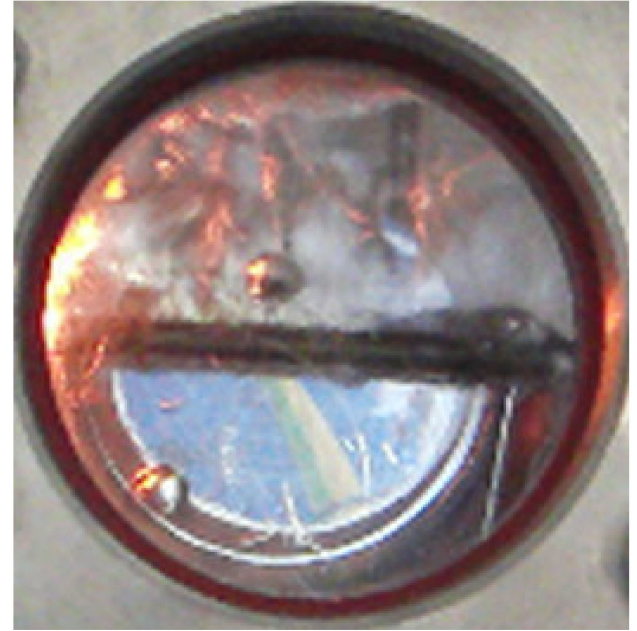

(b)

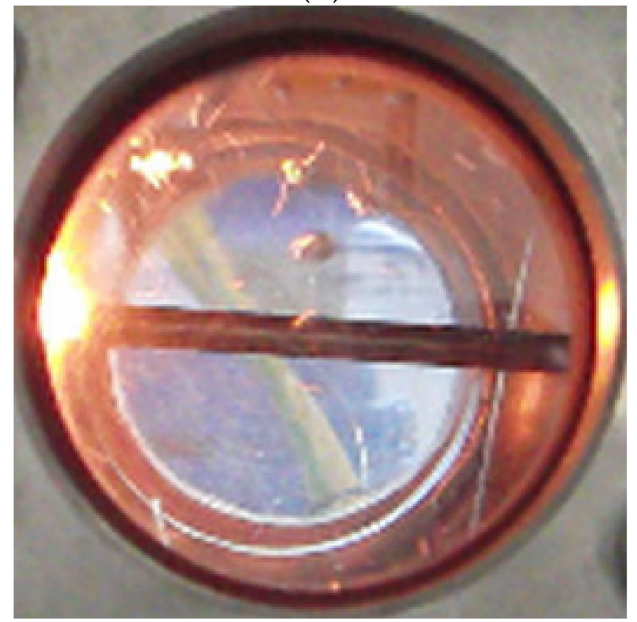

(d)

Figure 3. Burnout process: (a) developed NPB, (b) burnout incipience (left side of picture), (c) burnout, (d) end of process.

\section{Preparation and Characterization of Nanofluids}

The nanofluids tested were prepared by using the two-step method. Alumina $\left(\mathrm{Al}_{2} \mathrm{O}_{3}\right)$, titania $\left(\mathrm{TiO}_{2}\right)$ and copper $(\mathrm{Cu})$ were used as nanoparticles. According to the manufacturer (Sigma-Aldrich Co., St. Louis, MO, USA), the mean diameter of the nanoparticles was $47 \mathrm{~nm}$. Distilled, deionized water was applied as a base fluid. Ultrasonic vibration was used for $60 \mathrm{~min}$ in order to stabilize the dispersion of the nanoparticles. A bath-type ultrasonic washer, Sonica EP from Soltec Ltd. (Warsaw, Poland), worked at a frequency of $45 \mathrm{~Hz}$ and effective power of $100 \mathrm{~W}$. In order to avoid contamination of the boiling surface, dispersants were not used to stabilize the suspension. Nanoparticles were tested at the concentrations of $0.001 \%, 0.01 \%, 0.1 \%$ and $1 \%$ by weight. A CPC-401 gauge with electrode E-2627 from Elmetron (Zabrze, Poland) was used to measure pH of the tested nanofluids. An average value of $\mathrm{pH}$ of the tested nanofluids measured after fabrication at room temperature was about 7 .

Figure 4 shows SEM images of the nanoparticles tested, and Figure 5 displays photographs of the nanofluids produced.

The stability of the nanofluids produced was satisfactory. After 5 days, no visually observable sedimentation was detected. 


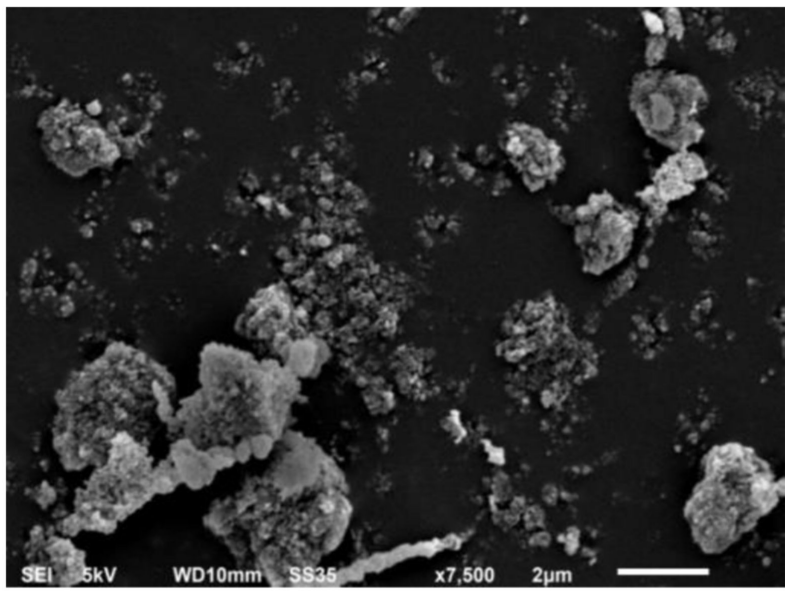

(a)

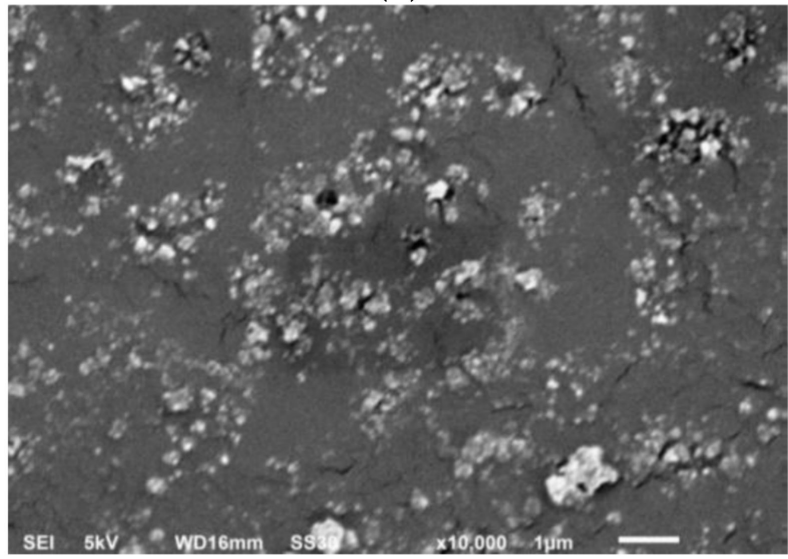

(b)

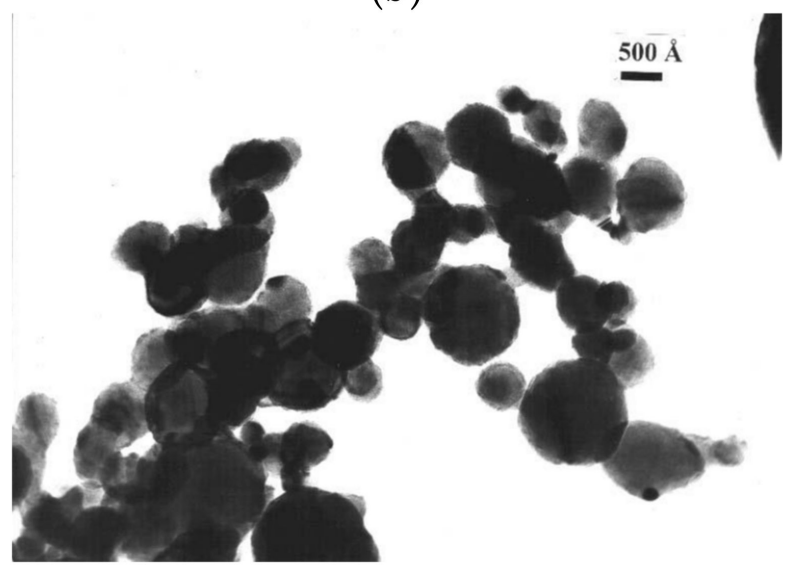

(c)

Figure 4. SEM images of nanoparticles tested: (a) water- $\mathrm{Al}_{2} \mathrm{O}_{3}$, (b) water- $\mathrm{TiO}_{2}$, (c) water-Cu. 


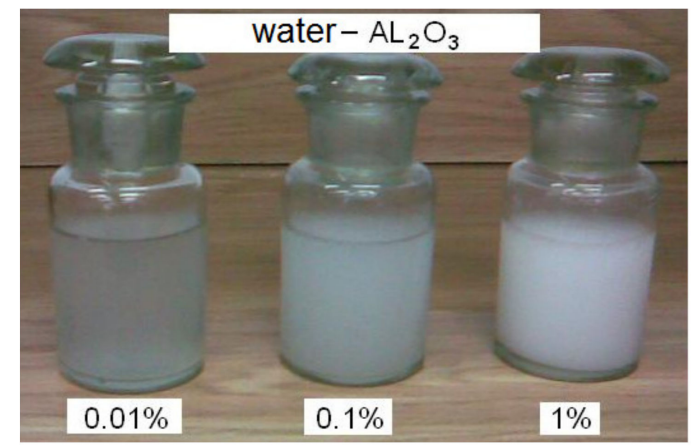

(a)

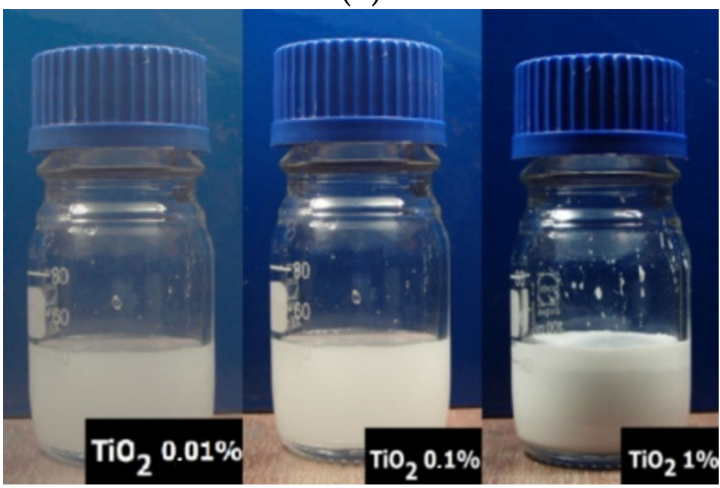

(b)

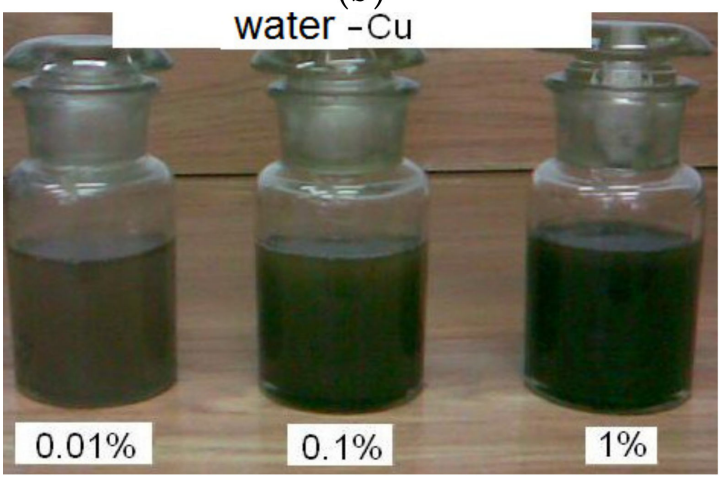

(c)

Figure 5. Photographs of the nanofluids tested: (a) water- $\mathrm{Al}_{2} \mathrm{O}_{3}$, (b) water- $\mathrm{TiO}_{2}$, (c) water-Cu.

\section{Data Reduction and Uncertainty Estimation}

The outer surface temperature, $t_{0}$, used for wall superheat determination was obtained as an analytical solution of the one-dimensional, steady-state heat conduction equation with uniform heat generation in the tube wall:

$$
t_{o}=t_{i}+\frac{U_{t} I_{t}}{4 \pi \lambda_{t} L}\left[\frac{2 \ln \left(D_{o} / D_{i}\right)}{\left(D_{o}^{2} / D_{i}^{2}\right)-1}-1\right]
$$

where $t_{i}\left({ }^{\circ} \mathrm{C}\right)$-temperature of the inner surface of the test tube, $U_{t}(\mathrm{~V})$-voltage drop, $I_{c}(\mathrm{~A})$-current, $D_{o}(\mathrm{~m})$ - outside diameter, $D_{i}(\mathrm{~m})$-inside diameter, $L(\mathrm{~m})$ - active length of a tube, $\lambda_{t}=15 \mathrm{~W} /(\mathrm{mK})$-thermal conductivity of stainless steel.

Wall superheat was calculated as

$$
\Delta T=t_{o}-t_{f}
$$


where $t_{f}$ was calculated as the arithmetic mean of four measured fluid temperatures (Figure 1).

$$
t_{f}=\frac{\sum_{i=1}^{i=4} t_{f, i}}{4}
$$

Heat flux was calculated as

$$
\dot{q}=\frac{U_{t} I_{t}}{\pi D_{0} L}
$$

Mean heat transfer coefficient was calculated as

$$
h=\frac{\dot{q}}{\Delta T}
$$

The uncertainties of the measured and calculated parameters were estimated with the mean-square method. The experimental uncertainty of heat flux was estimated as follows:

$$
\Delta q=\sqrt{\left(\frac{\partial \dot{q}}{\partial U_{t}} \Delta U_{t}\right)^{2}+\left(\frac{\partial \dot{q}}{\partial I_{t}} \Delta I_{t}\right)^{2}+\left(\frac{\partial \dot{q}}{\partial D_{o}} \Delta D_{o}\right)^{2}+\left(\frac{\partial \dot{q}}{\partial L} \Delta L\right)^{2}}
$$

where the absolute maximum measurement errors of the voltage drop $\Delta U_{t}$, current $\Delta I_{t}$, outer tube diameter $\Delta D_{o}$ and active length of a tube $\Delta L$ are $0.248 \mathrm{~V}, 1.57 \mathrm{~A}, 0.02 \mathrm{~mm}$, and 2 $\mathrm{mm}$, respectively. Therefore, the maximum overall experimental margins of error for heat flux extended from $\pm 4.3 \%$ for maximum heat flux up to $\pm 16.7 \%$ for minimum heat flux. The soldering of the tubes at both ends adds uncertainty to the length of the whole tube and attributes to the largest uncertainty in the heat flux.

The experimental uncertainty for the average heat transfer coefficient was calculated as

$$
\Delta h=\sqrt{\left(\frac{\partial h}{\partial \dot{q}} \Delta \dot{q}\right)^{2}+\left(\frac{\partial h}{\partial \Delta T} \delta \Delta T\right)^{2}}
$$

where the absolute measurement error of the wall superheat, $\delta \Delta \mathrm{T}$, estimated from the systematic error analysis, equals $\pm 0.2 \mathrm{~K}$. The maximum error for average heat transfer coefficient was estimated as $\pm 15.6 \%$.

\section{Results}

In order to validate the apparatus and experimental procedure, the present data were compared to the data obtained from Cooper correlation for distilled water boiling on horizontal, smooth, stainless steel tubes [69]:

$$
h=55 P_{r}^{0.12-0.434\left(\log R_{p)}\right.}\left[-0.434\left(\log P_{r}\right)\right]^{-0.55} M^{-0.5}(\dot{q})^{0.67}
$$

As seen in Figure 6, satisfactory agreement was obtained with data obtained for tube with $1.6 \mathrm{~mm}$, the smallest diameter.

Additionally, a series of experiments with pure water boiling on stainless steel tubes were conducted. Figure 7 shows boiling curves and the CHF region for distilled water on stainless steel tubes of $1.6,3$ and $5 \mathrm{~mm}$ outside diameters. The CHF recorded for $1075 \mathrm{~kW} / \mathrm{m}^{2}(1.6 \mathrm{~mm}), 1270 \mathrm{~kW} / \mathrm{m}^{2}(3 \mathrm{~mm})$, and $1120 \mathrm{~kW} / \mathrm{m}^{2}(5 \mathrm{~mm})$ are very close to the predictions made by use of the Kutateladze-Zuber correlation $[67,68]$ :

$$
\dot{q}_{K-Z}=0.131 \rho_{v} h_{f g}\left[\sigma g\left(\varrho_{l}-\varrho_{v}\right)\right]^{1 / 4}
$$

and Haramura-Katto correlation [70]:

$$
\dot{q}_{H-K}=A \dot{q}_{K-Z}
$$


where

$$
A=5.5\left(\frac{A_{v}}{A_{w}}\right)^{5 / 8}\left(1-\frac{A_{v}}{A_{w}}\right)^{5 / 16}\left[\left(\frac{\varrho_{f}}{\varrho_{v}}+1\right) /\left(\frac{11 \varrho_{f}}{16 \varrho_{v}}+1\right)^{3 / 5}\right]^{5 / 16}
$$

with

$$
\frac{A_{v}}{A_{w}}=0.0584\left(\frac{\varrho_{v}}{\varrho_{f}}\right)^{1 / 5}
$$

The results obtained explicitly prove that the test apparatus and procedure used in the present study provide reliable data.

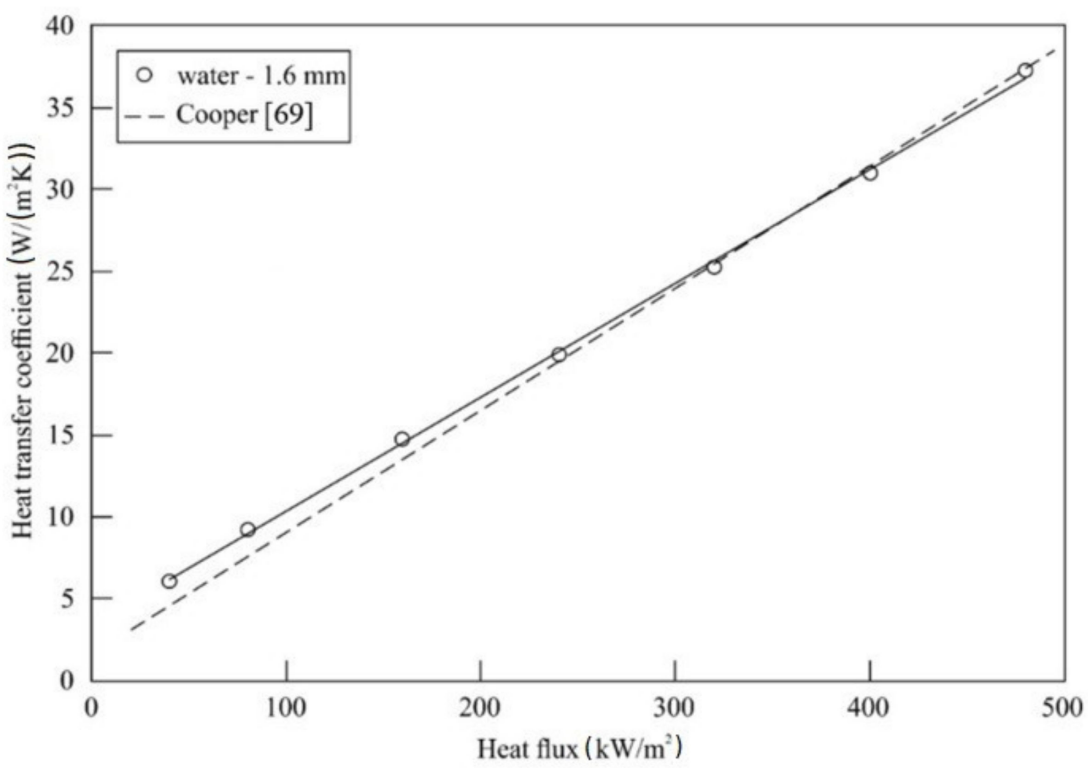

Figure 6. Validation of present experimental results with literature data.

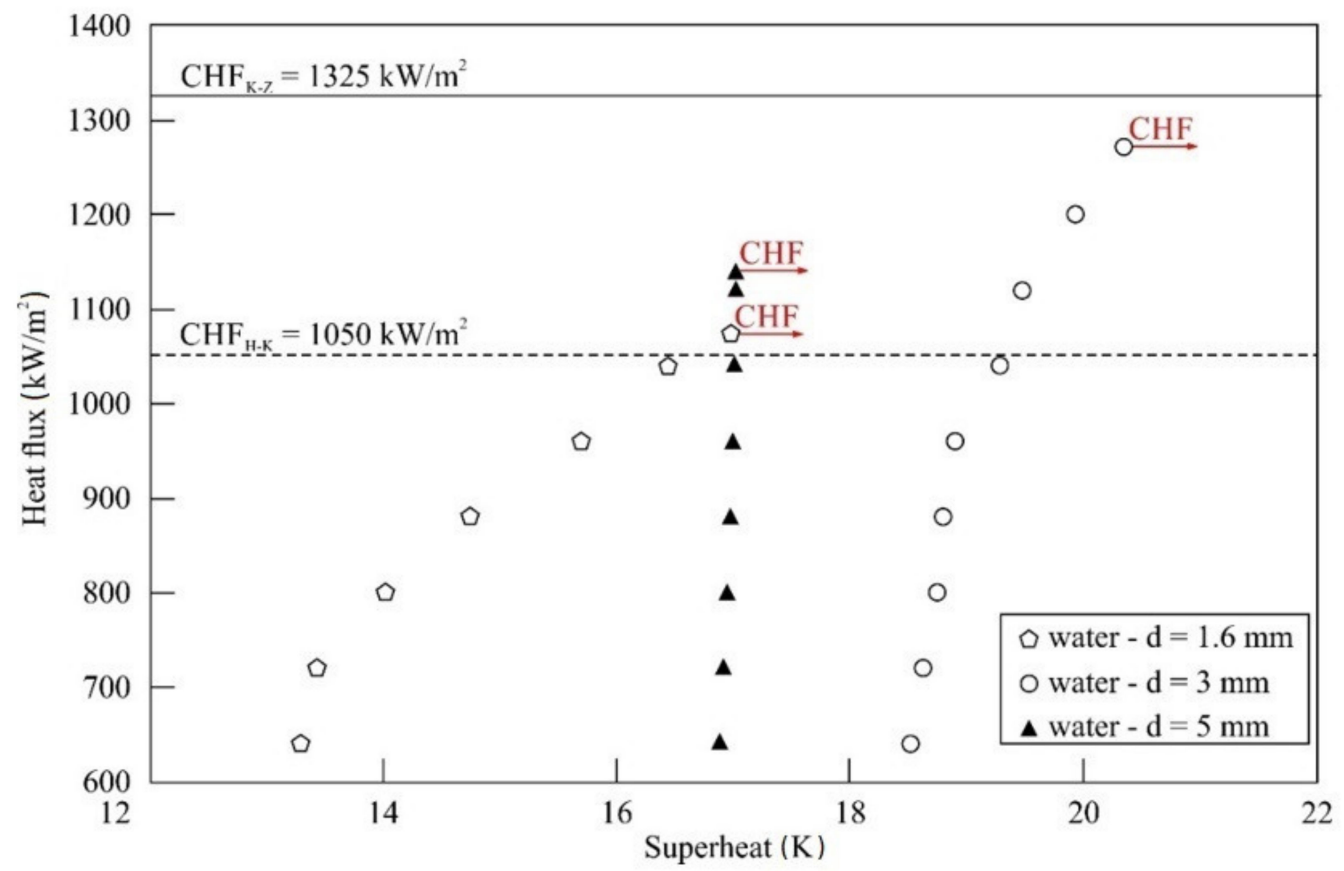

Figure 7. Boiling curves and CHF for deionized water on stainless steel tubes. 


\subsection{Impact of Tube Diameter}

As an example, Figure 8 presents the boiling curves and CHF region for water$\mathrm{TiO}_{2}$ nanofluid on SS tubes having 1.6, 3 and $5 \mathrm{~mm}$ outside diameters at atmospheric pressure for nanoparticle mass concentration of $1 \%$. The addition of $\mathrm{TiO}_{2}$ nanoparticles results in a dramatic increase in $\mathrm{CHF}$. As seen in Figure 8, the smaller the diameter, the higher the CHF recorded. The highest CHF $\left(1917 \mathrm{~kW} / \mathrm{m}^{2}\right)$ was obtained for the tube with $D_{o}=1.6 \mathrm{~mm}$ and was about $178 \%$ higher compared to boiling distilled water.

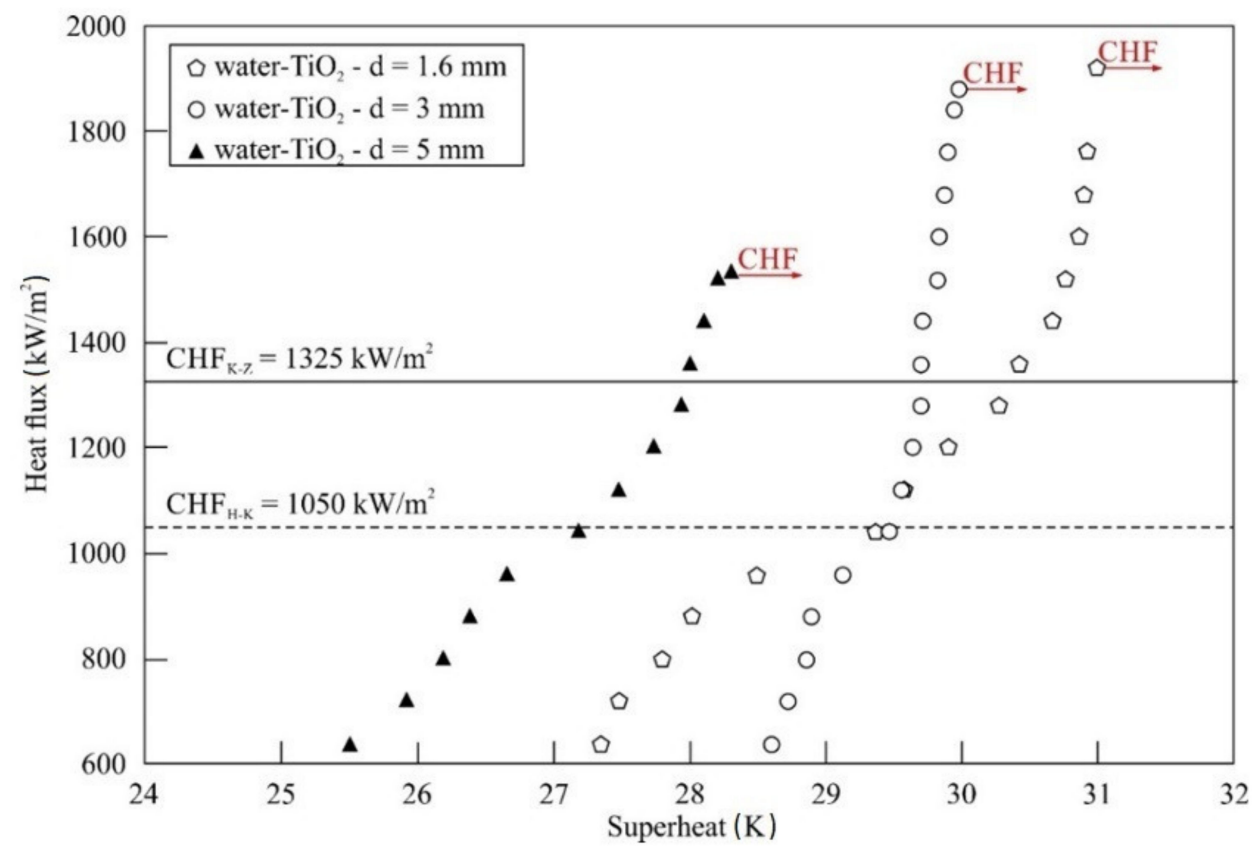

Figure 8. Boiling curves and $\mathrm{CHF}$ for water- $\mathrm{TiO}_{2}$ nanofluids.

\subsection{Impact of Nanoparticle Concentration and Material}

Figure 9 illustrates the influence of nanoparticle concentration on $\mathrm{CHF}$ during the process of boiling water- $\mathrm{Cu}$ nanofluid on an SS tube with $D_{o}=3 \mathrm{~mm}$ at atmospheric pressure for three tested nanoparticle mass concentrations, i.e., $0.001 \%, 0.01 \%$ and $0.1 \%$. As seen in Figure 9, CHF increases in line with nanoparticle concentration. However, only for the highest nanoparticle concentration tested, i.e., $0.1 \%$, CHF surpasses the values resulting from the Haramura-Katto and Kutateladze-Zuber correlations. Moreover, the addition of even a small amount of nanoparticles inhibits heat transfer in comparison with boiling distilled water. The boiling curves are shifted to the right, towards higher wall superheats.

Figure 10 displays boiling curves for water- $\mathrm{Al}_{2} \mathrm{O}_{3}$, water- $\mathrm{TiO}_{2}$ and water-Cu nanofluids on an SS tube with $D_{o}=3 \mathrm{~mm}$ for the same nanoparticle mass concentration of $0.01 \%$. As seen in Figure 10, the addition of $\mathrm{Al}_{2} \mathrm{O}_{3}$ and $\mathrm{TiO}_{2}$ nanoparticles resulted in much better $\mathrm{CHF}$ enhancement compared to $\mathrm{Cu}$ nanoparticles. CHF figures obtained for water- $\mathrm{Al}_{2} \mathrm{O}_{3}$ $\left(1818 \mathrm{~kW} / \mathrm{m}^{2}\right)$ and water- $\mathrm{TiO}_{2}\left(1757 \mathrm{~kW} / \mathrm{m}^{2}\right)$ nanofluids, compared to distilled water, were approximately $145 \%$ and $141 \%$ higher. The CHF recorded for water-Cu nanofluid $\left(1361.3 \mathrm{~kW} / \mathrm{m}^{2}\right)$ was close to the value of distilled water. 


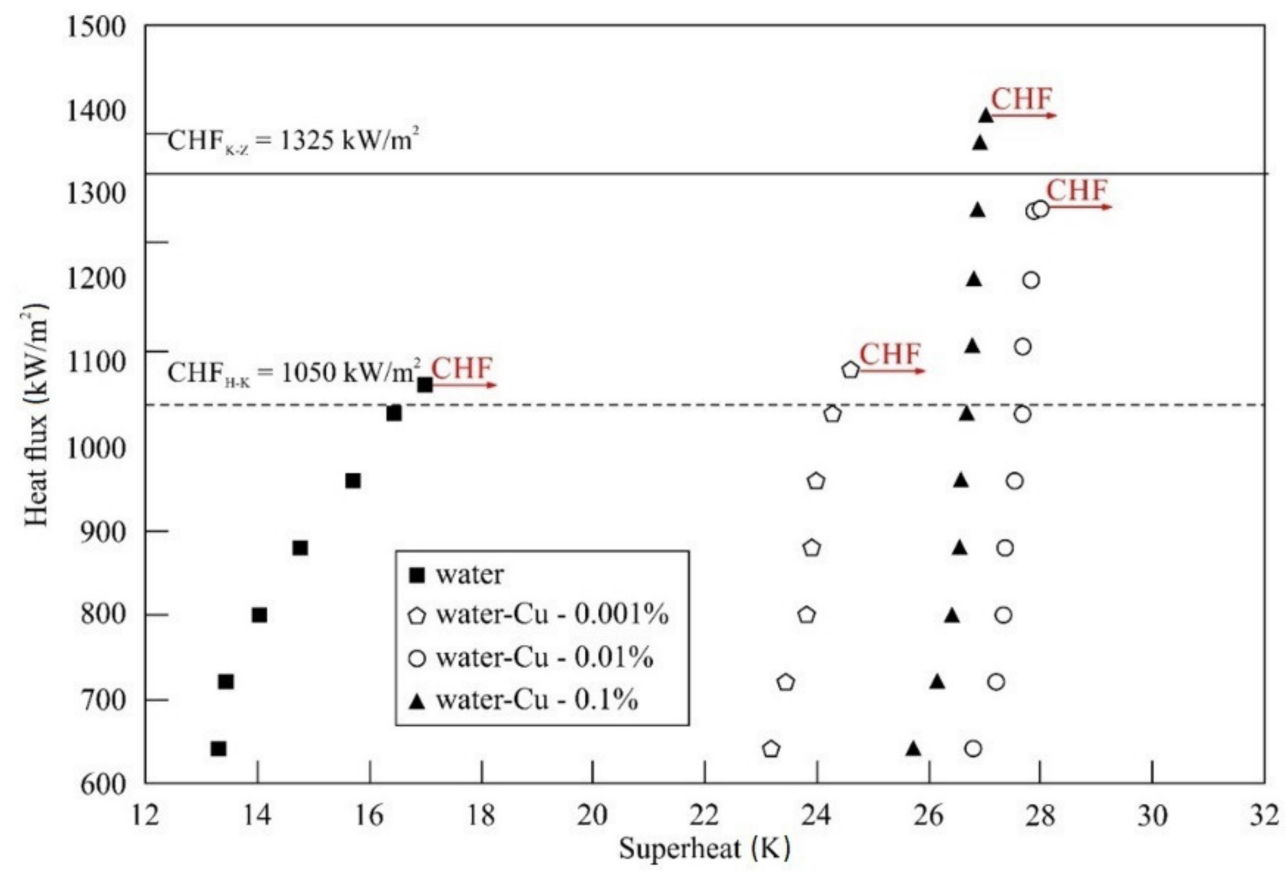

Figure 9. Boiling curves and $\mathrm{CHF}$ for water-Cu nanofluids.

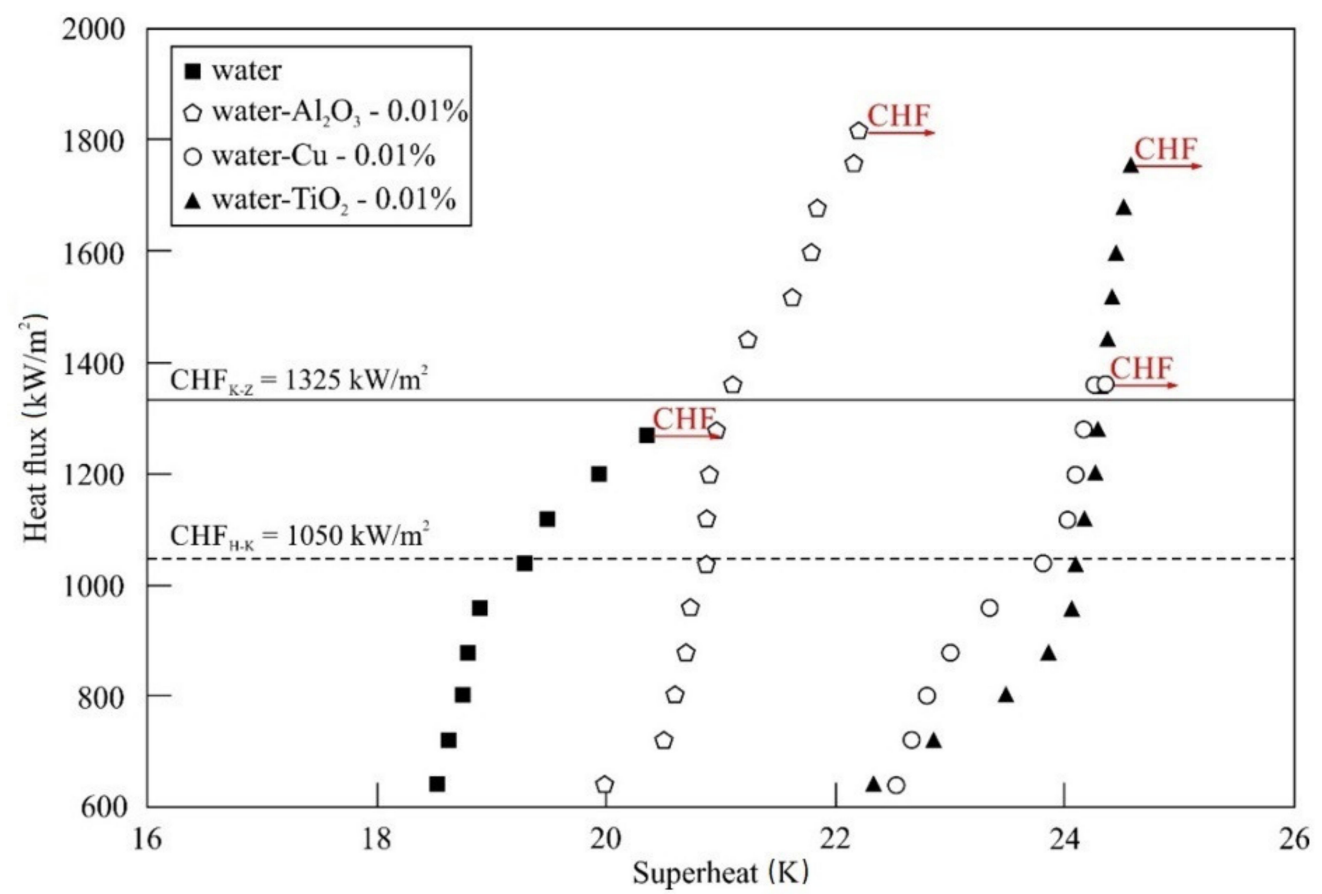

Figure 10. Boiling curves and $\mathrm{CHF}$ values for deionized water and water- $\mathrm{Al}_{2} \mathrm{O}_{3}$, water- $\mathrm{TiO} \mathrm{O}_{2}$ and water-Cu nanofluids on a stainless steel tube $\left(D_{o}=3 \mathrm{~mm}\right)$.

\subsection{Correlation Equation}

Explanation of the CHF mechanism is a real challenge. In the relevant literature, many hypotheses on $\mathrm{CHF}$ are reported. In all, five different categories of hypotheses are mentioned: hydrodynamic instability theory, macrolayer dryout theory, hot/dry spot theory, bubble interaction theory and interfacial liftoff theory. A brilliant review of these theories is presented in [71,72]. Besides hydrodynamic instability models, other models, the macrolayer dryout theory, hot/dry spot theory and bubble interaction theory, relate $\mathrm{CHF}$ to surface wettability [28]. In order to check the influence of the contact angle on CHF, 
the present results for water and the nanofluids tested were compared with predictions from Kandlikar's correlation for horizontal surfaces [73]:

$$
\dot{q}_{K}=\left(\frac{2}{\pi}\right)^{0.5}\left(\frac{1+\cos \beta}{16}\right) \varrho_{v} h_{f g}\left[\sigma g\left(\rho_{l}-\rho_{v}\right)\right]^{0.25}
$$

where $\beta$ is a contact angle.

As an example, Figure 11 shows the results of CHF measurements of the nanofluids tested with nanoparticle concentration of $0.01 \%$ as a function of contact angle. The dashed line represents predictions from Kandlikar's correlation for pure water. The empty points and black points represent predictions of the CHF for nanofluids with contact angles measured before and after the experiment, respectively. The details of the measurement technique are presented in [74]. As seen in Figure 11, contact angles for the boiled tubes are much smaller than for the tubes before the experiment. This means that the boiled surface exhibits better wettability. An explanation of this phenomenon is the formation of a nanocoating on the boiled surface.

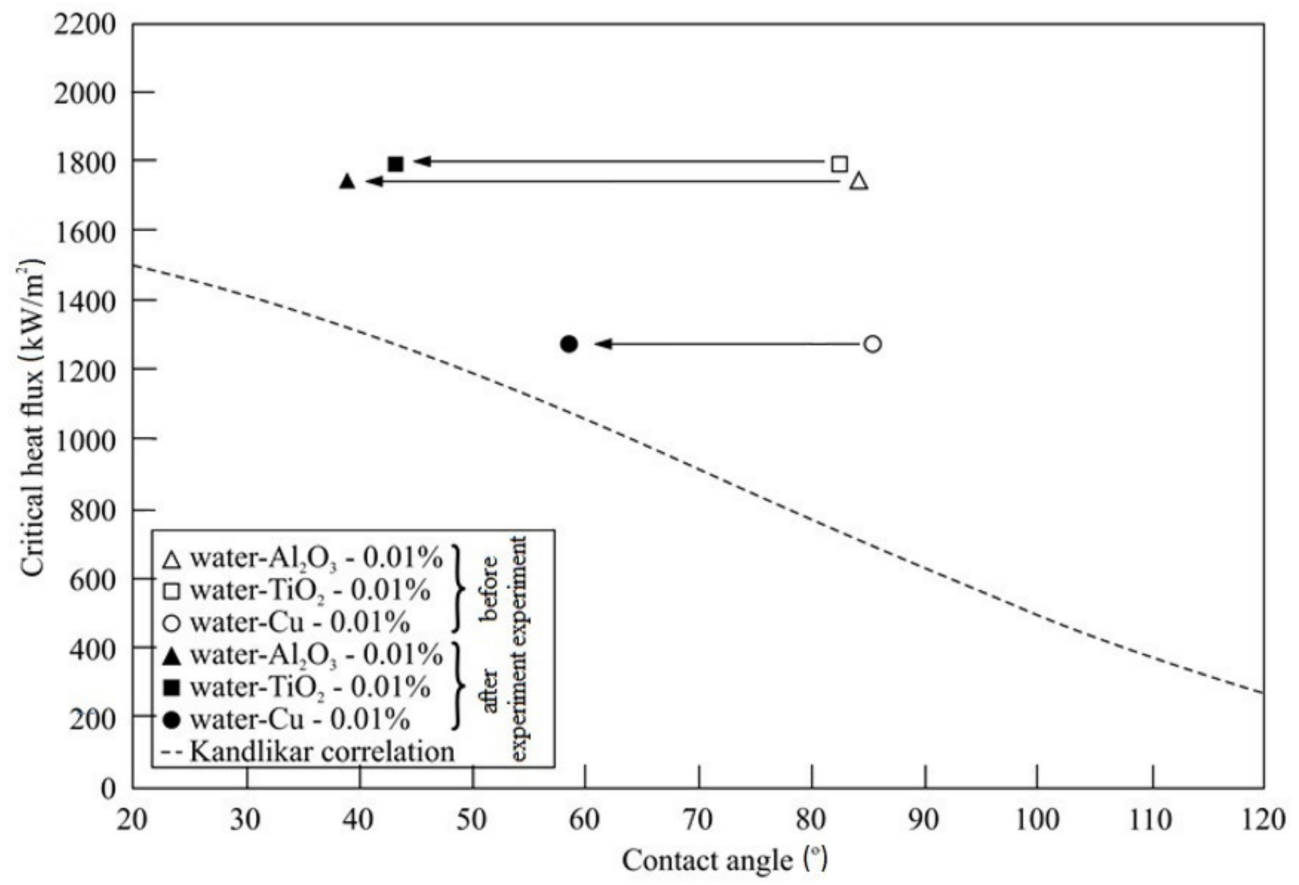

Figure 11. CHF against contact angle $\left(D_{o}=1.6 \mathrm{~mm}\right)$.

In order to generalize the results obtained, a correlation equation for the CHF of water- $\mathrm{Al}_{2} \mathrm{O}_{3}$, water- $\mathrm{TiO}_{2}$ and water- $\mathrm{Cu}$ nanofluids on horizontal tubes of small diameter during pool boiling was developed:

$$
\dot{q}_{C-R}=B \dot{q}_{K} \Phi^{n}
$$

where $\dot{q}_{K}$-Kandlikar's correlation (Equation (13)), $\Phi$-nanoparticle mass concentration,

$B$-tube material dependent constant, $n$ - exponent dependent on type and concentration of nanoparticles.

The material constant $(B=1.6)$ and exponents $n$ (Table 4$)$ in Equation (14) were determined by multidimensional regression analysis. 
Table 4. Values of exponent $n$ in Equation (14).

\begin{tabular}{cccc}
\hline Mass Concentration (\%) & & $\boldsymbol{n}(-)$ & $\mathbf{C u}$ \\
\hline & $\mathrm{Al}_{\mathbf{2}} \mathbf{O}_{\mathbf{3}}$ & $\mathrm{TiO}_{\mathbf{2}}$ & 0.0313 \\
\hline 0.001 & - & - & 0.0291 \\
\hline 0.01 & 0.0268 & 0.0237 & 0.0256 \\
\hline 0.1 & 0.0273 & 0.0284 & - \\
\hline 1 & 0.0361 & 0.0348 & \\
\hline
\end{tabular}

Figure 12 shows a comparison of the experimental results for the same nanoparticle mass concentrations of $0.01 \%$ obtained for tubes of all diameters tested with the predictions made from the developed correlation (Equation (14)) and contact angles measured after the experiment. The maximum discrepancy between the measured and predicted values of $\mathrm{CHF}$ is equal to $20 \%$ for water $-\mathrm{Al}_{2} \mathrm{O}_{3}$ and water- $\mathrm{TiO}_{2}$ nanofluids, and a tube with $D_{o}=5 \mathrm{~mm}$.

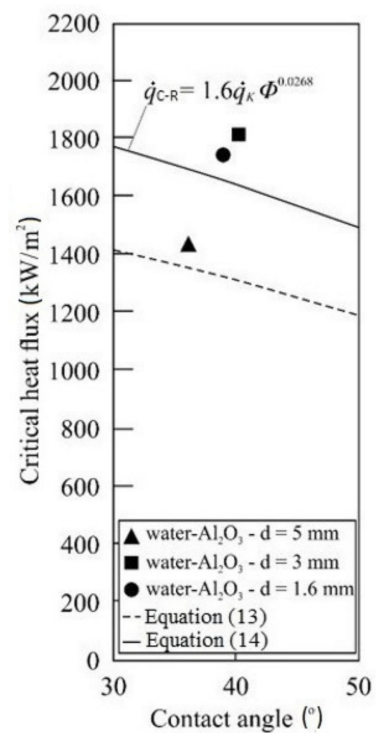

(a)

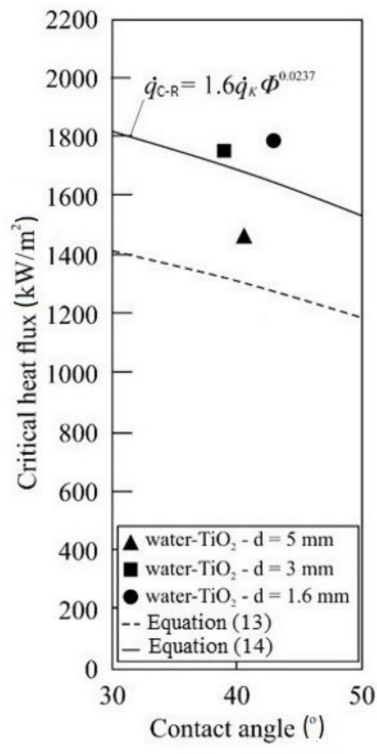

(b)

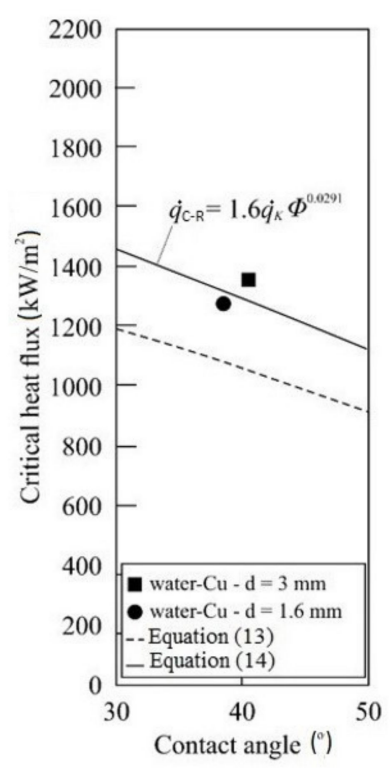

(c)

Figure 12. Comparison of measured and calculated CHFs against contact angle for the nanofluids tested: (a) water- $\mathrm{Al}_{2} \mathrm{O}_{3},(\mathbf{b})$ water- $\mathrm{TiO}_{2}$, (c) water-Cu.

Figure 13 shows comparison of the CHFs obtained during the experiments and CHFs calculated from the developed correlation (Equation (14)). All measurement points lie within a band of $\pm 20 \%$. Noting the complexity of the burnout process, the agreement obtained is satisfactory.

\subsection{Nanocoating on Heating Surface}

Unlike thick metallic coatings that have no effect on CHF [75], extremely thin nanocoating changes the wettability of the boiling surface, leading to a CHF enhancement. Figure 14 shows SEM images of the tube surface $\left(D_{o}=1.6 \mathrm{~mm}\right)$ with a nanocoating formed during the process of boiling water- $\mathrm{TiO}_{2}$ nanofluid with nanoparticle mass concentration of $0.01 \%$. Figure $14 \mathrm{a}$ shows that the nanocoating has a heterogeneous structure and covers the tube surface unevenly. Figure 14b, which presents an SEM image of a very large magnification, reveals the high porosity of the nanocoating deposited. 


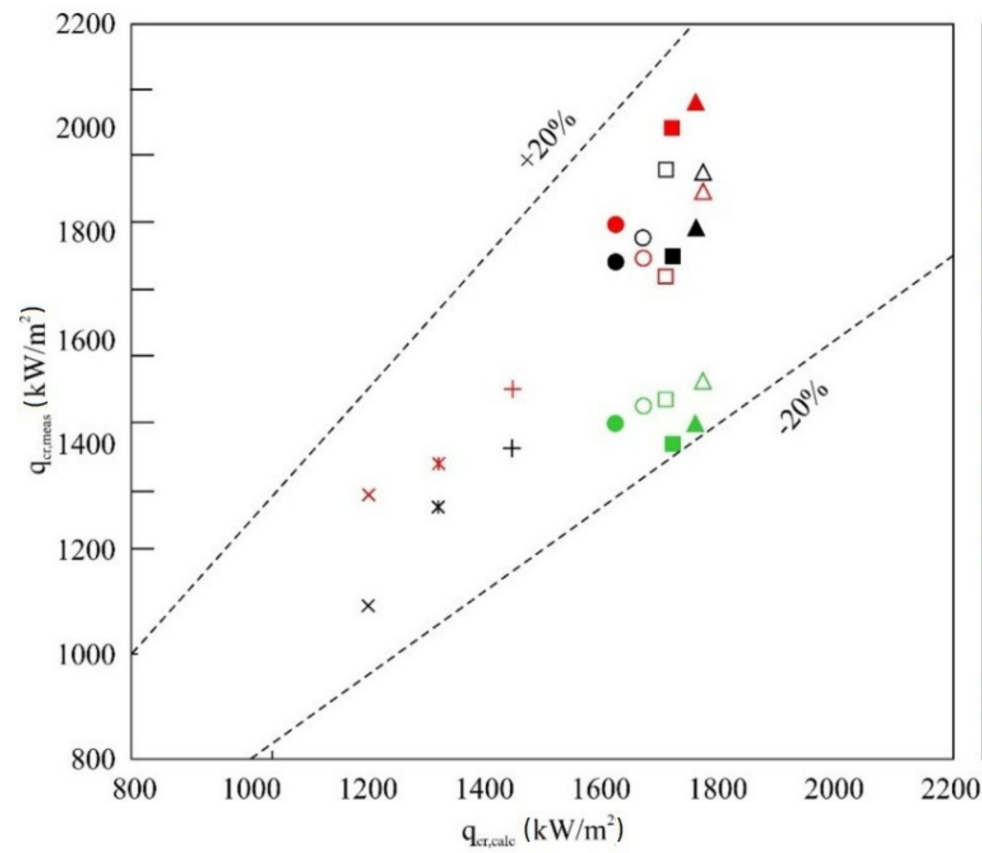

water- $\mathrm{Al}_{2} \mathrm{O}_{3}-0.01 \%-\mathrm{d}=1.6 \mathrm{~mm}$

water- $\mathrm{Al}_{2} \mathrm{O},-0.1 \%-\mathrm{d}=1.6 \mathrm{~mm}$

$\Delta$ water- $\mathrm{Al}_{2} \mathrm{O}_{3}-1 \%-\mathrm{d}=1.6 \mathrm{~mm}$

- water- $\mathrm{Al}_{2} \mathrm{O}_{3}-0.01 \%-\mathrm{d}=3 \mathrm{~mm}$

water- $\mathrm{Al}_{2} \mathrm{O}-0.1 \%-\mathrm{d}=3 \mathrm{~mm}$

$\Delta$ water- $\mathrm{Al}_{2} \mathrm{O}_{3}-1 \%-\mathrm{d}=3 \mathrm{~mm}$

water- $\mathrm{Al}_{2} \mathrm{O}-0.01 \%-\mathrm{d}=5 \mathrm{~mm}$

water- $\mathrm{Al}_{2} \mathrm{O}_{2}-0.1 \%-\mathrm{d}=5 \mathrm{~mm}$

$\Delta$ water- $\mathrm{Al}_{2} \mathrm{O}_{3}-1 \%-\mathrm{d}=5 \mathrm{~mm}$

O water- $\mathrm{TiO}_{2}-0.01 \%-\mathrm{d}=1.6 \mathrm{~mm}$

water- $\mathrm{TiO},-0.1 \%-\mathrm{d}=1.6 \mathrm{~mm}$

$\Delta$ water- $\mathrm{TiO}_{2}-1 \%-\mathrm{d}=1.6 \mathrm{~mm}$

O water- $\mathrm{TiO}_{2}-0.01 \%-\mathrm{d}=3 \mathrm{~mm}$

$\square$ water- $\mathrm{TiO}_{2}-0.1 \%-\mathrm{d}=3 \mathrm{~mm}$

$\triangle$ water- $\mathrm{TiO}_{2}-1 \%-\mathrm{d}=3 \mathrm{~mm}$

water- $\mathrm{TiO}_{2}-0.01 \%-\mathrm{d}=5 \mathrm{~mm}$

water- $\mathrm{TiO},-0.1 \%-\mathrm{d}=5 \mathrm{~mm}$

water- $\mathrm{TiO}_{2}-1 \%-\mathrm{d}=5 \mathrm{~mm}$

water-Cu- $0.001 \%-\mathrm{d}=1.6 \mathrm{~mm}$

* water- $\mathrm{Cu}-0.01 \%-\mathrm{d}=1.6 \mathrm{~mm}$

+ water-Cu $-0.1 \%-d=1.6 \mathrm{~mm}$

$\times$ water-Cu $-0.001 \%-\mathrm{d}=3 \mathrm{~mm}$

* water-Cu $-0.01 \%-\mathrm{d}=3 \mathrm{~mm}$

+ water-Cu- $0.1 \%-\mathrm{d}=3 \mathrm{~mm}$

Figure 13. Comparison of the experimental data with predictions.

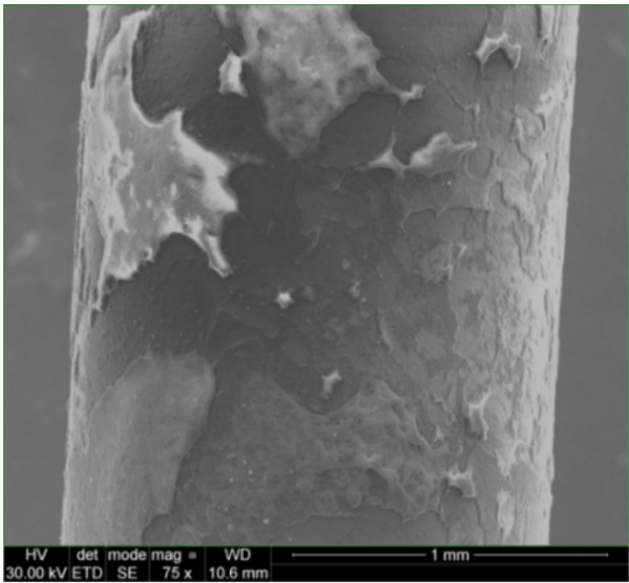

(a)

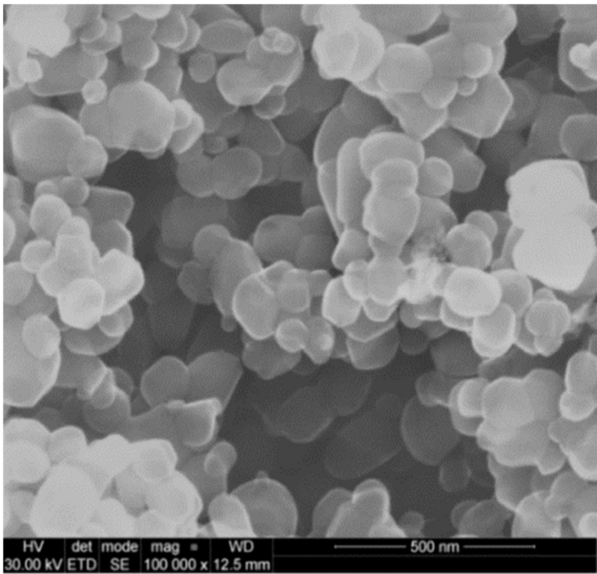

(b)

Figure 14. SEM photographs of heating surface after burnout: (a) magnification $(\times 75),(b)$ magnification $(\times 100,000)$.

\section{Discussion}

Although there is a consensus that the nanocoating is responsible for CHF enhancement, there is no agreement regarding the mechanism of nanocoating formation. The first mechanism was suggested by Kim et al. [27] and confirmed experimentally by Kwark et al. [45]. According to this hypothesis, nanoparticle coating formation is a result of the evaporation of a microlayer containing nanoparticles. The second approach explains nanocoating formation as a mutual interaction between nanoparticles and the heating surface, influenced by adhesion forces and the agglutination process [36].

In the relevant literature, factors other than the improved wettability of the nanocoated surface are responsible for CHF enhancement of nanofluids. Kim and Kim [32] suggested that the increase in $\mathrm{CHF}$ is a result of displacing the contact line in the direction of a hot, dry patch under the growing steam bubble. Displacement of the contact line is a result of capillary wicking in porous nanocoating, allowing fresh liquid to flow into the dry patch area and thus delaying the irreversible spread of the hot, dry patch process that leads to CHF. Park and Bang [76] observed that porous nanocoating affected the distance 
between steam pillars created during the process of nanofluid boiling and, as a result, changed the critical wavelength conditioning of the Helmholtz instability. Sefiane [77] explains the increase in CHF as a result of a delay in contact line depinning for nanofluids, compared to base liquids. A longer-lasting state of steam bubble pinning to the heating surface limits the spread of the dry patch under the bubble, thus delaying the CHF. The longer pinning compared to base liquid is caused by structural disjoining pressure resulting from the accumulation of nanoparticles being ordered in a wedge near the contact line. Wen [78] developed a CHF model built on the idea of structural disjoining pressure. Wen showed that the presence of nanoparticles in liquid caused significant displacement of the contact line in the direction of the vapor dry patch. The structural disjoining pressure causes significantly better nanofluid wetting, which limits the spread of the dry patch and, as a result, delays CHF. Park et al. [50] neglect the role of wettability and capillarity of G/GO nanocoatings in CHF enhancement. Instead, they stress the fact that extremely high thermal conductivity of G and GO improves the thermal activity of the heater [79], depending on the characteristic dimension and material effusivity of the heater used.

\section{Conclusions}

Present experiments lead to the following conclusions:

- For all nanofluids tested and stainless steel tubes used, an improvement of CHF compared to distilled water was observed.

- The maximum enhancement of $\mathrm{CHF}$ was obtained for water- $-\mathrm{TiO}_{2}$ nanofluid and a stainless steel tube of the smallest diameter, $D_{o}=1.6 \mathrm{~mm}$. Compared to distilled water, the improvement was about $178 \%$.

- It was established that self-deposited nanocoatings result in substantial improvement in the wettability of the boiling surface, which is what leads to CHF enhancement.

- Formation of the nanocoatings results in heat transfer degradation-boiling curves are shifted left, towards higher wall superheats.

- An empirical correlation equation for predicting the $\mathrm{CHF}$ of water-based nanofluids was developed and verified for $\mathrm{Al}_{2} \mathrm{O}_{3}, \mathrm{TiO}_{2}$ and $\mathrm{Cu}$ nanoparticles and mass concentrations of $0.001 \%, 0.01 \%, 0.1 \%$ and $1 \%$.

Author Contributions: Conceptualization, J.T.C.; methodology, J.T.C. and K.R.; software, K.R.; validation, J.T.C.; formal analysis, J.T.C.; investigation, K.R.; data curation, K.R.; writing—original draft preparation, J.T.C.; writing—review and editing, J.T.C.; funding acquisition, J.T.C. Both authors have read and agreed to the published version of the manuscript. All authors have read and agreed to the published version of the manuscript.

Funding: This research received no external funding.

Conflicts of Interest: The authors declare no conflict of interest.

\section{Nomenclature}

$\begin{array}{lll}\mathrm{D}_{\mathrm{i}} & \text { Inner diameter of heated tube } & (\mathrm{m}) \\ \mathrm{D}_{\mathrm{o}} & \text { Outer diameter of heated tube } & (\mathrm{m}) \\ \mathrm{g} & \text { Gravitational acceleration } & \left(\mathrm{m} / \mathrm{s}^{2}\right) \\ \mathrm{h} & \text { Heat transfer coefficient } & \left(\mathrm{W} /\left(\mathrm{m}^{2} \mathrm{~K}\right)\right) \\ \mathrm{h}_{\mathrm{fg}} & \text { Latent heat of vaporization } & (\mathrm{J} / \mathrm{kg}) \\ \mathrm{I}_{\mathrm{t}} & \text { Current } & (\mathrm{A}) \\ \mathrm{k} & \text { Thermal conductivity } & (\mathrm{W} /(\mathrm{m} \mathrm{K})) \\ \mathrm{L} & \text { Tube length } & (\mathrm{m}) \\ \mathrm{M} & \text { Molecular weight } & (\mathrm{kg} / \mathrm{kmol}) \\ q & \text { Heat flux } & \left(\mathrm{W} / \mathrm{m}^{2}\right) \\ \mathrm{P}_{\mathrm{r}} & \text { Reduced pressure } & (-) \\ \mathrm{R}_{\mathrm{a}} & \text { Mean roughness } & (\mu \mathrm{m}) \\ \mathrm{R}_{\mathrm{p}} & \text { Mean roughness } & (\mu \mathrm{m})\end{array}$




\begin{tabular}{|c|c|c|}
\hline$t$ & Temperature & $\left({ }^{\circ} \mathrm{C}\right)$ \\
\hline $\mathrm{U}_{\mathrm{t}}$ & Voltage drop & $(\mathrm{V})$ \\
\hline$\Delta T$ & Temperature difference & $(\mathrm{K})$ \\
\hline \multicolumn{3}{|c|}{ Greek symbols } \\
\hline$\beta$ & Contact angle & $\left({ }^{\circ}\right)$ \\
\hline$\lambda$ & Thermal conductivity & $(\mathrm{W} /(\mathrm{mK}))$ \\
\hline$\Phi$ & Nanoparticle mass concentration & $(-)$ \\
\hline$\rho$ & Density & $\left(\mathrm{kg} / \mathrm{m}^{3}\right)$ \\
\hline$\sigma$ & Surface tension & $\left(\mathrm{J} / \mathrm{m}^{2}\right)$ \\
\hline \multicolumn{3}{|c|}{ Subscripts } \\
\hline $\mathrm{f}$ & Fluid & \\
\hline 1 & Liquid & \\
\hline $\mathrm{m}$ & Mass & \\
\hline $\mathrm{nf}$ & Nanofluid & \\
\hline $\mathrm{t}$ & Tube & \\
\hline $\mathrm{v}$ & Vapor & \\
\hline vol & Volume & \\
\hline wt & Mass & \\
\hline \multicolumn{3}{|c|}{ Abbreviations } \\
\hline $\mathrm{CHF}$ & Critical Heat Flux & \\
\hline CNT & Carbon Nanotubes & \\
\hline DW & Deionized Water & \\
\hline EEWL & Electrical Explosion of Wire in Liquids & \\
\hline EG & Ethylene Glycol & \\
\hline FCNT & Functionalized Carbon Nanotube & \\
\hline G & Graphene & \\
\hline GO & Graphene Oxide & \\
\hline GON & Graphene Oxide Nanosheets & \\
\hline HTC & Heat Transfer Coefficient & \\
\hline NPB & Nucleate Pool Boiling & \\
\hline OD & Outside Diameter & \\
\hline PG & Polyethylene Glycol & \\
\hline PVP & Polyvinylpyrrolidone & \\
\hline RGO & Reduced Graphene Oxide & \\
\hline SDBS & Sodium Dodecyl Benzene Sulfonate & \\
\hline SDS & Sodium Dodecyl Sulfate & \\
\hline SEM & Scanning Electron Microscope & \\
\hline SS & Stainless Steel & \\
\hline xGnPs & Exfoliated Graphite Nanoplatelets & \\
\hline
\end{tabular}

\section{References}

1. Xie, S.; Beni, M.S.; Cai, J.; Zhao, J. Review of critical-heat-flux enhancement methods. Int. J. Heat Mass Transf. 2018, 122, $275-289$. [CrossRef]

2. Liang, G.; Mudawar, I. Review of pool boiling enhancement with additives and nanofluids. Int. J. Heat Mass Transf. 2018, 124, 423-453. [CrossRef]

3. Kim, H. Enhancement of critical heat flux in nucleate boiling of nanofluids: A state-of-art review. Nanoscale Res. Lett. 2011, 6, 415. [CrossRef] [PubMed]

4. Ahn, H.S.; Kim, M.H. A Review on Critical Heat Flux Enhancement with Nanofluids and Surface Modification. J. Heat Transf. 2012, 134, 024001.

5. Kamatchi, R.; Venkatachalapathy, S. Parametric study of pool boiling heat transfer with nanofluids for the enhancement of critical heat flux: A review. Int. J. Therm. Sci. 2015, 87, 228-240. [CrossRef]

6. Bolton, J.; Liu, L.; Hinks, J.; Chai, J. Critical Heat Flux Enhancement Using Nanofluids and Hybrid Nanofluids: A Review. Int. J. Nanosci. Nanotechnol. 2018, 4, 35-56.

7. Yao, S.; Teng, Z. Effect of Nanofluids on Boiling Heat Transfer Performance. Appl. Sci. 2019, 9, 2818. [CrossRef]

8. Liang, G.; Mudawar, I. Review of pool boiling enhancement by surface modification. Int. J. Heat Mass Transf. 2019, 128, 892-933. [CrossRef]

9. Vafaei, S.; Borca-Tasciuc, T. Role of nanoparticles on nanofluid boiling phenomenon: Nanoparticle deposition. Chem. Eng. Res. Des. 2014, 92, 842-856. [CrossRef] 
10. Shojaeian, M.; Koşar, A. Pool boiling and flow boiling on micro- and nanostructured surfaces. Exp. Therm. Fluid Sci. 2015, 63, 45-73. [CrossRef]

11. Li, X.; Cole, I.; Tu, J. A review of nucleate boiling on nanoengineered surfaces-The nanostructures, phenomena and mechanisms. Int. J. Heat Mass Transf. 2019, 141, 20-33. [CrossRef]

12. Sezer, N.; Khan, S.A.; Koç, M. Amelioration of the pool boiling heat transfer performance by colloidal dispersions of carbon black. Int. J. Heat Mass Transf. 2019, 137, 599-608. [CrossRef]

13. Moghadasi, H.; Malekian, N.; Saffari, H.; Gheitaghy, A.M.; Zhang, G.Q. Recent Advances in the Critical Heat Flux Amelioration of Pool Boiling Surfaces Using Metal Oxide Nanoparticle Deposition. Energies 2020, 13, 4026. [CrossRef]

14. Kim, D.E.; Yu, D.I.; Jerng, D.W.; Kim, M.H.; Ahn, H.S. Review of boiling heat transfer enhancement on micro/nanostructured surfaces. Exp. Therm. Fluid Sci. 2015, 66, 173-196. [CrossRef]

15. Lee, S.; Choi, U.S.; Li, S.; Eastman, J.A. Measuring thermal conductivity of fluids containing oxide nanoparticles. J. Heat Transf. 1999, 121, 280-289. [CrossRef]

16. Cieśliński, J.T.; Kaczmarczyk, T.Z. Pool boiling of water- $\mathrm{Al}_{2} \mathrm{O}_{3}$ and water-Cu nanofluids on horizontal smooth tubes. Nanoscale Res. Lett. 2011. [CrossRef]

17. Cieśliński, J.T.; Kaczmarczyk, T.Z. Pool boiling of water- $\mathrm{Al}_{2} \mathrm{O}_{3}$ and water-Cu nanofluids on porous coated tubes. Heat Transf. Eng. 2015, 36, 553-563. [CrossRef]

18. You, S.M.; Kim, J.H.; Kim, K.H. Effect of nanoparticles on critical heat flux of water in pool boiling heat transfer. Appl. Phys. Lett. 2003, 83, 3374-3376. [CrossRef]

19. Vassallo, P.; Kumar, R.; D'Amico, S. Pool boiling heat transfer experiments in silica-water nanofluids. Int. J. Heat Mass Transf. 2004, 47, 407-411. [CrossRef]

20. Dinh, N.; Tu, J.; Theofanous, T. Hydrodynamic and physico-chemical nature of burnout in pool boiling. In Proceedings of the 5th International Conference on Multiphase Flow, ICMF'04, Yokohama, Japan, 30 May-4 June 2004. paper No. 296 (CD-ROM).

21. Moreno, G.; Oldenburg, S.J.; You, S.M.; Kim, J.H. Pool boiling heat transfer of alumina-water, zinc oxide-water and aluminawater-ethylene glycol nanofluids. In Proceedings of the HT2005 ASME Summer Heat Transfer Conference, San Francisco, CA, USA, 17-22 July 2005; pp. 625-632.

22. Bang, I.C.; Chang, S.H. Boiling heat transfer performance and phenomena of $\mathrm{Al}_{2} \mathrm{O}_{3}$-water nanofluids from a plain surface in a pool. Int. J. Heat Mass Transf. 2005, 48, 2407-2419. [CrossRef]

23. Milanova, D.; Kumar, R. Role of ions in pool boiling heat transfer of pure and silica nanofluids. Appl. Phys. Lett. 2005, 87, 233107. [CrossRef]

24. Jackson, J.E.; Borgmeyer, B.V.; Wilson, C.A.; Cheng, P.; Bryan, J.E. Characteristics of Nucleate Boiling with Gold Nanoparticles in water. In Proceedings of the IMECE2006, Chicago, IL, USA, 5-10 November 2006.

25. Kim, H.; Kim, J.; Kim, M.H. Effect of nanoparticles on CHF enhancement in pool boiling of nano-fluids. Int. J. Heat Mass Transf. 2006, 49, 5070-5074. [CrossRef]

26. Kim, H.; Kim, J.; Kim, M. CHF enhancement in pool boiling of water- $\mathrm{TiO}_{2}$ nanofluids: Effect of nanoparticle-coating on heating surface. In Proceedings of the 13th International Heat Transfer Conference, Sydney, Australia, 13-18 August 2006. paper NAN-22 (CD-ROM).

27. Kim, S.J.; Bang, I.C.; Buongiorno, J.; Hu, L.W. Effects of nanoparticle deposition on surface wettability influencing boiling heat transfer in nanofluids. Appl. Phys. Lett. 2006, 89, 153107. [CrossRef]

28. Kim, S.; Bang, I.; Buongiorno, J.; Hu, L. Surface wettability change during pool boiling of nanofluids and its effect on critical heat flux. Int. J. Heat Mass Transf. 2007, 50, 4105-4116. [CrossRef]

29. Kashinath, M.R. Parameters Affecting Critical Heat Flux on Nanofluids: Heater size, Pressure Orientation and Anti-Freeze Addition. Master's Thesis, University of Texas, Arlington, TX, USA, 2006.

30. Milanova, D.; Kumar, R.; Kuchibhatla, S.; Seal, S. Heat transfer behavior of oxide nanoparticles in pool boiling experiment. In Proceedings of the International Fourth Conference on Nanochannels, Microchannels and Minichannels (ICNMM2006), Limerick, Ireland, 19-21 June 2006.

31. Kim, H.; Kim, J.; Kim, M. Experimental study on CHF characteristics of water-TiO 2 nano-fluids. Nucl. Eng. Technol. 2006, 38, 61-68.

32. Kim, H.D.; Kim, M.H. Effect of nanoparticle deposition on capillary wicking that influences the critical heat flux in nanofluids. Appl. Phys. Lett. 2007, 91, 014104. [CrossRef]

33. Kim, H.; Kim, J.; Kim, M. Experimental studies on CHF characteristics of nano-fluids at pool boiling. Int. J. Multiph. Flow 2007, 33, 691-706. [CrossRef]

34. Liu, Z.; Xiong, J.; Bao, R. Boiling heat transfer characteristics of nanofluids in a flat heat pipe evaporator with micro-grooved heating surface. Int. J. Multiph. Flow 2007, 33, 1284-1295. [CrossRef]

35. Coursey, J.; Kim, J. Nanofluid boiling: The effect of surface wettability. Int. J. Heat Fluid Flow 2008, 29, 1577-1585. [CrossRef]

36. Liu, Z.; Liao, L. Sorption and agglutination phenomenon of nanofluids on a plain heating surface during pool boiling. Int. J. Heat Mass Transf. 2008, 51, 2593-2602. [CrossRef]

37. Milanova, D.; Kumar, R. Heat transfer behavior of silica nanoparticles in pool boiling experiment. J. Heat Transf. 2008, $130,042401$. [CrossRef] 
38. Golubovic, M.N.; Madhawa Hettiarachchi, H.D.; Worek, W.M.; Minkowycz, W.J. Nanofluids and critical heat flux, experimental and analytical study. Appl. Therm. Eng. 2009, 29, 1281-1288. [CrossRef]

39. Jo, B.; Jeon, P.S.; Yoo, J.; Kim, H.J. Wide range parametric study for the pool boiling of nanofluids with a circular plate heater. J. Vis. 2009, 12, 37-46. [CrossRef]

40. Kumar, R.; Milanova, D. Effect of surface tension on nanotube nanofluids. Appl. Phys. Lett. 2009, 94, 073107. [CrossRef]

41. Kim, H.; Kim, M. Experimental study of the characteristics and mechanism of pool boiling CHF enhancement using nanofluids. Int. J. Heat Mass Transf. 2009, 45, 991-998. [CrossRef]

42. Park, K.J.; Jung, D.; Shim, S.E. Nucleate boiling heat transfer in aqueous solutions with carbon nanotubes up to critical heat fluxes. Int. J. Multiph. Flow 2009, 35, 525-532. [CrossRef]

43. Kim, H.; DeWitt, G.; McKrell, T.; Buongiorno, J.; Hu, L.W. On the quenching of steel and zircaloy spheres in water-based nanofluids with alumina, silica and diamond nanoparticles. Int. J. Multiph. Flow 2009, 35, 427-438. [CrossRef]

44. Kathiravan, R.; Kumar, R.; Gupta, A.; Chandra, R. Preparation and pool boiling characteristics of copper nanofluids over a flat plate heater. Int. J. Heat Mass Transf. 2010, 53, 1673-1681. [CrossRef]

45. Kwark, S.M.; Kumar, R.; Moreno, G.; Yoo, J.; You, S.M. Pool boiling characteristics of low concentration nanofluids. Int. J. Heat Mass Transf. 2010, 53, 972-981. [CrossRef]

46. Kwark, S.M.; Moreno, G.; Kumar, R.; Moon, H.; You, S.M. Nanocoating characterization in pool boiling heat transfer of pure water. Int. J. Heat Mass Transf. 2010, 53, 4579-4587. [CrossRef]

47. Kwark, S.M.; Amaya, M.; Kumar, R.; Moreno, G.; You, S.M. Effects of pressure, orientation, and heater size on pool boiling of water with nanocoated heaters. Int. J. Heat Mass Transf. 2010, 53, 5199-5208. [CrossRef]

48. Liu, Z.H.; Yang, X.F.; Xiong, J.G. Boiling characteristics of carbon nanotube suspensions under sub-atmospheric pressures. Int. J. Therm. Sci. 2010, 49, 1156-1164. [CrossRef]

49. Kim, H.; Ahn, H.S.; Kim, M.H. On the mechanism of pool boiling critical heat flux enhancement in nanofluids. J. Heat Transf. 2010, 132, 061501. [CrossRef]

50. Park, S.D.; Lee, S.W.; Kang, S.; Bang, I.C.; Kim, J.H.; Shin, H.S.; Lee, D.W.; Lee, D.W. Effects of nanofluids containing graphene/graphene-oxide nanosheets on critical heat flux. Appl. Phys. Lett. 2010, 97, 023103. [CrossRef]

51. Truong, B.; Hu, L.W.; Buongiorno, J.; McKrell, T. Modification of sandblasted plate heaters using nanofluids to enhance pool boiling critical heat flux. Int. J. Heat Mass Transf. 2010, 53, 85-94. [CrossRef]

52. Kathiravan, R.; Kumar, R.; Gupta, A.; Chandra, R. Preparation and pool boiling characteristics of copper silver nanofluids over a flat plate heater. Heat Transf. Eng. 2012, 33, 69-78. [CrossRef]

53. Park, E.J.; Park, S.D.; Bang, I.C.; Park, Y.-B.; Park, H.W. Critical heat flux characteristics of nanofluids based on exfoliated graphite nanoplatelets (xGnPs). Mater. Lett. 2012, 81, 193-197. [CrossRef]

54. Lee, J.H.; Lee, T.; Jeong, Y.H. Experimental investigation on the CHF enhancement of pool boiling using water-based nanofluid at higher pressure. In Proceedings of the ICAPP 2013, Jeju Island, Korea, 14-18 April 2013. Paper No. 131.

55. Hiswankar, S.C.; Kshirsagar, J.M. Determination Of Critical Heat Flux In Pool Boiling Using ZnO Nanofluids. Int. J. Eng. Res. Technol. 2013, 2, 2091-2095.

56. Park, E.; Bang, I.; Park, H. Critical heat flux (CHF) enhancement of the nanofluids by the electrical explosion of a wire in liquids (EEWL) process. Nanotech 2012, 2, 353-356.

57. Kole, M.; Dey, T.K. Pool Boiling Heat Transfer and Critical Heat Flux Enhancement of Copper Nanoparticles Dispersed in Distilled Water. J. Nanofluids 2014, 3, 1-12. [CrossRef]

58. Song, S.L.; Lee, J.H.; Chang, S.H. CHF enhancement of SiC nanofluid in pool boiling experiment. Exp. Therm. Fluid Sci. 2014, 52, 12-18. [CrossRef]

59. Sarafraz, M.M.; Hormozi, F.; Silakhori, M.; Peyghambarzadeh, S.M. On the fouling formation of functionalized and nonfunctionalized carbon nanotube nano-fluids under pool boiling condition. Appl. Therm. Eng. 2016, 95, 433-444. [CrossRef]

60. He, Y.; Li, H.; Hu, Y.; Wang, X.; Zhu, J. Boiling heat transfer characteristics of ethylene glycol and water mixture based ZnO nanofluids in a cylindrical vessel. Int. J. Heat Mass Transf. 2016, 98, 611-615. [CrossRef]

61. Sulaiman, M.Z.; Matsuo, D.; Enoki, K.; Okawa, T. Systematic measurements of heat transfer characteristics in saturated pool boiling of water-based nanofluids. Int. J. Heat Mass Transf. 2016, 102, 264-276. [CrossRef]

62. Ham, J.; Kim, H.; Shin, Y.; Cho, H. Experimental investigation of pool boiling characteristics in $\mathrm{Al}_{2} \mathrm{O}_{3}$ nanofluid according to surface roughness and concentration. Int. J. Therm. Sci. 2017, 114, 86-97. [CrossRef]

63. Kim, J.H.; Kim, J.M.; Jerng, D.W.; Kim, E.Y.; Ahn, H.S. Effect of aluminum oxide and reduced graphene oxide mixtures on critical heat flux enhancement. Int. J. Heat Mass Transf. 2018, 116, 858-870. [CrossRef]

64. Hwang, W.-K.; Choy, S.; Song, S.L.; Lee, J.; Hwang, D.S.; Lee, K.-Y. Enhancement of nanofluid stability and critical heat flux in pool boiling with nanocellulose. Carbohydr. Polym. 2019, 213, 393-402. [CrossRef]

65. Lienhard, J.H.; Dhir, V.K. Hydrodynamic prediction of peak pool-boiling heat fluxes from finite bodies. J. Heat Transf. 1973, 95, 152-158. [CrossRef]

66. Bakhru, N.; Lienhard, J.H. Boiling from small cylinders. Int. J. Heat Mass Transf. 1972, 15, 2011-2025. [CrossRef]

67. Zuber, N. On the stability of boiling heat transfer. Trans. Am. Soc. Mech. Eng. 1958, 80, 711-720.

68. Zuber, N. The dynamics of vapor bubbles in nonuniform temperature fields. Int. J. Heat Mass Transf. 1961, 2, 83-98. [CrossRef] 
69. Cooper, M.G. Heat Flow in Saturated Nucleate pool Boiling-A Wide-Ranging Examination Using Reduced Properties. Adv. Heat Transf. 1984, 16, 157-239.

70. Haramura, Y.; Katto, Y. A new hydrodynamic model of critical heat flux, applicable widely to both pool and forced convection boiling on submerged bodies in saturated liquids. Int. J. Heat Mass Transf. 1983, 26, 389-399. [CrossRef]

71. Liang, G.; Mudawar, I. Pool boiling critical heat flux (CHF)_Part 1: Review of mechanisms, models, and correlations. Int. J. Heat Mass Transf. 2018, 117, 1352-1367. [CrossRef]

72. Liang, G.; Mudawar, I. Pool boiling critical heat flux (CHF)—Part 2: Assessment of models and correlations. Int. J. Heat Mass Transf. 2018, 117, 1368-1383. [CrossRef]

73. Kandlikar, S.G. A theoretical model to predict pool boiling CHF incorporating effects of contact angle and orientation. J. Heat Transf. 2001, 123, 1071-1079. [CrossRef]

74. Cieśliński, J.T.; Krygier, K.A. Sessile droplet contact angle of water- $\mathrm{Al}_{2} \mathrm{O}_{3}$, water-TiO $\mathrm{T}_{2}$ and water-Cu nanofluids. Exp. Therm. Fluid Sci. 2014, 59, 258-263. [CrossRef]

75. Cieśliński, J.T. Nucleate pool boiling on porous metallic coatings. Exp. Therm. Fluid Sci. 2002, 25, 557-564. [CrossRef]

76. Park, S.D.; Bang, I.C. Experimental study of a universal CHF enhancement mechanism in nanofluids using hydrodynamic instability. Int. J. Heat Mass Transf. 2014, 70, 844-850. [CrossRef]

77. Sefiane, K. On the role of structural disjoining pressure and contact line pinning in critical heat flux enhancement during boiling of nanofluids. Appl. Phys. Lett. 2006, 89, 044106. [CrossRef]

78. Wen, D. Mechanisms of thermal nanofluids on enhanced critical heat flux (CHF). Int. J. Heat Mass Transf. 2008, 51, 4958-4965. [CrossRef]

79. Arik, M.; Bar-Cohen, A. Effusivity-based correlation of surface property effects in pool boiling CHF of dielectric liquids. Int. J. Heat Mass Transf. 2003, 46, 3755-3764. [CrossRef] 